Check for updates

Cite this: RSC Adv., 2019, 9, 17220

Received 11th April 2019

Accepted 14th May 2019

DOI: $10.1039 / c 9 r a 02726 b$

rsc.li/rsc-advances

\section{Experimental and theoretical investigation of cyclometalated phenylpyridine iridium(III) complex based on flavonol and ibuprofen ligands as potent antioxidant $\uparrow+$}

\author{
Leila Tabrizi, (D)*a Thi Le Anh Nguyen (D) *b and Duy Quang Dao (iD) b
}

An Ir(III) complex was synthesized using mixed ligands of biological importance, namely ibuprofen, flavonol and 2-phenylpyridine. The compound was characterized by ${ }^{1} \mathrm{H}-\mathrm{NMR},{ }^{13} \mathrm{C}-\mathrm{NMR}$ and TOF-MS spectroscopies and elemental analysis. Structures of the complex and its ligands were also calculated by density functional theory using B3LYP/Lanl2dz//6-31G(d) level of theory. Analyses of electrostatic potential, natural population, and frontier orbitals of the molecules as well as the calculation of intrinsic thermochemical properties such as bond dissociation enthalpy, ionization potential, electron affinity and proton affinity in the gas phase and in solvents (water and pentylethanoate) give the first indication that the complex is a potential antioxidant. The latter even shows better antioxidant capacity than the parent ligands. The antioxidant properties of the complex and its ligands were experimentally evaluated by studying the free radical scavenging activity towards $\mathrm{HO} 0^{\circ}, \mathrm{NO}^{*}, \mathrm{DPPH}^{*}$ and $\mathrm{ABTS}^{\cdot+}$ radicals. Further computational work on the antioxidant processes such as the single electron transfer, the proton loss, the formal hydrogen transfer (FHT) and the radical adduct formation reactions was conducted. Results show that the FHT reaction is the mechanism responsible for the radical scavenging activity of the complex towards $\mathrm{HO}^{\circ}, \mathrm{HOO}^{\circ}, \mathrm{NO}^{\circ}$ and $\mathrm{DPPH}^{*}$ radicals while $\mathrm{ABTS}^{++}$seems to be scavenged by an electron-donating mechanism. The FHT was further determined as a hydrogen-atom transfer but not a proton-couple electron transfer mechanism.

\section{Introduction}

Recent findings in biochemistry and related sciences have strengthened the connections between oxidative stress,

${ }^{a}$ School of Chemistry, National University of Ireland, University Road, Galway, H91 TK33, Ireland.E-mail: leila.tabrizi@nuigalway.ie

${ }^{b}$ Institute of Research and Development, Duy Tan University, 03 Quang Trung, Danang, 550000, Vietnam. E-mail: nguyenthileanh@dtu.edu.vn

$\dagger$ Electronic supplementary information (ESI) available: ${ }^{1} \mathrm{H}-\mathrm{NMR},{ }^{13} \mathrm{C}-\mathrm{NMR}$, TOF MS spectra of Ir(III) complex; HPLC chromatogram; experimental methods for DPPH', $\mathrm{HO}^{\circ}, \mathrm{NO}^{*}$, and $\mathrm{ABTS}^{*+}$ radical scavenging assays and cytotoxicity, cell culture and ROS production experiments; results for percentage of $\mathrm{DPPH}^{\circ}, \mathrm{HO}^{\circ}, \mathrm{NO}$, and ABTS $^{*+}$ radicals scavenged and ESR spectra of four studied radicals as a function of concentration; in vitro antitumor activity of Ir(III) complex and two ligands towards A549, A2780 and A2780cis cancer cells; IC $_{50}$ concentrations of $\operatorname{Ir}(\mathrm{III})$ complex and cis-platin against three studied cancer cell lines; ROS levels in A549 cells as determined by NBT assays; NBO charges of Ir(III) complex; $\Delta H^{0}$ and $\Delta G^{0}$ for HAT reactions with $\mathrm{HOO}^{\circ}$ and $\mathrm{HO}^{*}$ radicals; energy of the optimized structures of TSs for the RAF reaction with HOO ${ }^{\circ}$ radical; $\Delta H^{0}$ and $\Delta G^{0}$ for RAF reactions with $\mathrm{HOO}^{\circ}$ and $\mathrm{HO}^{\bullet}$ radicals; $\Delta H^{0}$ and $\Delta G^{0}$ for RAF and HAT reactions of $\mathrm{HOO}^{\bullet}$ and $\mathrm{HO}^{*}$ with flavonol and ibuprofen; TS and SOMO orbitals of HAT and RAF reaction between ibuprofen and flavonol with $\mathrm{HO}^{\circ} / \mathrm{HOO}^{\circ}$ radicals; Cartesian coordinates of molecules and TSs of HAT and RAF reactions. See DOI: 10.1039/c9ra02726b

\$ The manuscript was written through contributions of all authors. All authors have given approval to the final version of the manuscript. inflammation and severe diseases in the human body. ${ }^{1,2}$ Longtime exposure to oxidative stress was proved to lead to chronic inflammation and later sickness and diseases. Both cancers and non-cancer diseases such as Parkinson's, Alzheimer's, diabetes and hypertension were reported to have a relationship with oxidative stress. For the last forty years, the use of cis-platin and its analogues for the treatment of certain kinds of cancers has helped to save and lengthen lives of many patients. Since then, there has been an exponential increasing of attention paid to the use of metallodrugs in the treatment of diseases, ${ }^{3}$ in which several late transition metal complexes, i.e. $\mathrm{Ir}, \mathrm{Rh}, \mathrm{Ru}$ and $\mathrm{Os}$, have shown great potential for biological targets. ${ }^{4-8}$

Meanwhile, Ir(III) complexes have found important applications in fields of research ranging from materials to catalysis based on their interesting photo-physical and photo-chemical properties. ${ }^{9}$ They are known to be efficient phosphors in OLEDs or imaging agent and sensors. ${ }^{10-14}$ In particular, there have been several attempts to use Ir-based carbene compounds or complexes as antitumor agents; a series of half-sandwich Ir(III) complexes were synthesized or modeled and reported as potential anticancer drugs. ${ }^{15-20}$ Indeed, one can expect for the new Ir(III) complexes, as well as for other metallodrugs, to (i) get 
stronger and more selective effects against tumors, (ii) extend the spectrum of cancer treatment and (iii) overcome the limits of Pt-based drugs such as the platin resistance and other severe side-effects.

We are interested in studying the antioxidant activity of Ir(III) complexes, which is believed as a fundamental point to search for further biological activities such as antiinflammation or anticancer properties. One can easily imagine, in such metallodrugs, that both metal ion and ligands could play crucial roles for the deactivation and quenching of reactive oxidant species (ROS), probably through redox reaction for the metal complex and other more complicated mechanisms for ligands., ${ }^{321}$ In order to design such on-demand Ir complexes, the smart choice of ligands becomes obviously the key step. We mainly aim to choose ligands exhibiting strong antioxidant properties or confirmed positive biological activity in human health. The final target is to achieve metal complexes having stronger antioxidant properties than those of the parent components.

Flavonol, a member of the natural flavonoids, is acknowledged for having benefit to human health mostly as antidepressant and antioxidant. In particular, flavonol has been documented to have antibacterial, anti-inflammation and antiallergic properties or even to reduce the risk of heart diseases and to slowdown the ageing procedure. ${ }^{21}$ The presence of a hydroxyl group at the position next to the carboxyl group seems to promote stronger antioxidant properties and also makes flavonol a perfect candidate for metal ion chelation. ${ }^{22}$ Several flavonol complexes of V(IV), ${ }^{23} \mathrm{Fe}(\mathrm{III}),{ }^{24} \mathrm{~Pb}(\mathrm{II}),{ }^{25}$ $\mathrm{Al}(\mathrm{III})^{26}$ and $\mathrm{Zn}(\mathrm{II})^{27}$ have been reported. In spite of that, there has been no in-depth study of the antioxidant or biological activities of the compounds, except in the case of the $\mathrm{Zn}$ (II) complex, which indeed shows strong antidiabetic activity in rats comparable to that of gliclazide, a standard drug for diabetes. $^{27}$

Ibuprofen is currently one of the most popular nonsteroidal anti-inflammatory drugs to treat fever, pain and inflammation. Metal complexes of ibuprofen and its derivatives, including those of $\mathrm{Cu}(\mathrm{II}),{ }^{28} \mathrm{Ru}(\mathrm{II}, \mathrm{III})^{29}$ and $\mathrm{Au}(\mathrm{I})^{30}$ were documented. While $\mathrm{Cu}(\mathrm{II})$ and $\mathrm{Ru}(\mathrm{II}, \mathrm{III})$ complexes show a similar effect on carrageenan-induced edema in rats as the parent drug (ibuprofen), they show less gastric irritation and are more protective to ulceration than ibuprofen. ${ }^{29}$ The Au(I) complex shows positive antibacterial activity in vitro against Gramnegative (E. coli and $P$. aeruginosa) and Gram-positive ( $S$. aureus) microorganisms. ${ }^{30}$

The octahedral coordination of $\operatorname{Ir}(\mathrm{III})$ cation might be completed with 2-phenylpyridine. In-depth studies have been reported on the use of Ir(III) complexes of 2-phenylpyridine as well as of polypyridine as anticancer ${ }^{31}$ or imaging agents in live cells. ${ }^{32}$ For the moment, cellular uptake and the cytotoxicity of these complexes still limit their bioapplications.

In this paper, we report a combination of experimental and theoretical studies of an Ir(III) coordination compound constructed from ligands with biological activities: flavonol, ibuprofen and 2-phenylpyridine. The compound was first synthesized and characterized by ${ }^{1} \mathrm{H}-\mathrm{NMR},{ }^{13} \mathrm{C}-\mathrm{NMR}$, and MS spectroscopies and elemental analysis. Optimized geometry and internal electronic properties of the molecule, i.e. electrostatic potential (ESP) map, natural population analysis (NPA) and frontier orbitals (HOMO, LUMO), were also computed using the density functional theory (DFT) approach. The antioxidant properties of the complex and two of the ligands (ibuprofen and flavonol) were then experimentally studied in terms of free radical scavenging activity (RSA) towards $\mathrm{HO}^{\circ}, \mathrm{NO}^{\circ}, \mathrm{DDPH}^{*}$ and $\mathrm{ABTS}^{\circ}{ }^{+}$. Theoretical investigation of thermochemical properties such as bond dissociation enthalpy (BDE), proton affinity (PA), ionization potential (IP) and electron affinity (EA) was conducted in the gas phase and in water to evaluate the antioxidant potentials of the compound through the electron- and the protondonating/accepting capacities. Finally, DFT calculation was helpful in obtaining evidence of the free radical scavenging mechanisms by studying single electron transfer (SET), proton loss (PL), formal hydrogen transfer (FHT) and radical adduct formation (RAF) reactions between the radicals $\left(\mathrm{HO}^{\circ}\right.$, $\mathrm{HOO}^{\circ}, \mathrm{NO}^{\circ}, \mathrm{DPPH}^{\circ}$ and $\mathrm{ABTS}^{\circ+}$ ) and the Ir(III) complex at the most favorable positions. Potential energy profiles (PEPs) of reactions and natural bond orbital (NBO) analysis were used to elucidate the mechanism of the antioxidant activity through FHT and RAF reactions. Especially, further analyses of frontier orbitals of transition states (TSs) and NBO were used as key elements to distinguish the FHT mechanism as hydrogen atom transfer (HAT) or proton couple electron transfer (PCET).

\section{Methods}

\subsection{Materials and methods}

All reagents and solvents were purchased from SigmaAldrich and Fisher Scientific and used without further purification. Microwave-assisted reactions were carried out in an Ethos UP microwave oven using $85 \mathrm{~mL}$ TFM Teflon closed vessels equipped with temperature sensor, pressure controller and a magnetic stirrer bar. ${ }^{1} \mathrm{H}$ and ${ }^{13} \mathrm{C}$ nuclear magnetic resonance (NMR) spectra were recorded with a Bruker-400 $\mathrm{MHz}$ spectrometer at ambient temperature in DMSO- $d_{6}$. Electrospray ionization mass spectra were recorded with a Waters LCT Premier XE spectrometer in positiveor negative-ion mode. Elemental analyses were performed with an EA 3000 CHNS. Electronic absorption spectra were obtained with a Shimadzu Lambda-1600 UV-visible spectrophotometer.

Electron spin resonance (ESR) spectra were obtained with a Varian spectrometer using the following conditions: $3385.0 \mathrm{G}$ field, $20.0 \mathrm{mV}$ power, $100.0 \mathrm{kHz}$ modulation frequency, $1.0 \mathrm{G}$ amplitude and $300 \mathrm{~s}$ sweep time. The temperature was kept at $20{ }^{\circ} \mathrm{C}$ using a cooling water circulator.

\subsection{Computational methods}

All calculations were performed using the Gaussian 09, revision E.01 package. $^{33}$ Geometry optimization and frequency 
calculations of all structures, TSs, intermediate species and products were performed using the hybrid functional B3LYP without any constraint. Two different basis sets were employed in combination, the Lanl2dz basis set for Ir and the 6-31G(d) basis set for $\mathrm{C}, \mathrm{H}, \mathrm{N}$, and $\mathrm{O}$ elements, as previously recommended. ${ }^{34,35}$ The Lanl $2 \mathrm{dz}$ set was selected as it can appropriately describe the electronic structure of transition metals while the 6-31G(d) set was chosen for balancing the accuracy of the calculation and the computed time. Moreover, calculation with the combination of these two basis sets was reported to provide good correlations with experimental results for different Ir complexes. ${ }^{14,35}$ The geometry of the complex was first studied with different spin configurations and the lowest energy one was kept for further investigations. All single-point calculations were performed with the same basis sets. Bulk effect of solvent was studied by single-point calculation using the polarizable continuum model IEF-PCM with water and pentylethanoate (PEA) as the solvents which were chosen to represent the lipid media in human bodies. ${ }^{36,37}$

In order to evaluate the antioxidant potential of the $\operatorname{Ir}(\mathrm{III})$ complex and its ligands, the most conventional reactions were firstly studied as follows: HAT, PL and SET. ${ }^{37}$ The thermochemical properties of the Ir complex and ligands, such as BDE, PA, IP and EA studied in the gas phase and in solvents, were then deduced from the corresponding equations (see ESI for more details $\dagger$ ). The second steps for the single electron transfer followed by proton transfer (SETPT) and sequential proton loss electron transfer (SPLET) reactions were only evaluated for the most probable positions on the Ir(III) complex.

Second, thermochemical properties and kinetics of the reactions between the antioxidant and free radicals, e.g. $\mathrm{HO}^{\circ}$, $\mathrm{HOO}^{\circ}, \mathrm{NO}^{\circ}, \mathrm{DPPH}^{*}$ and $\mathrm{ABTS}^{\circ+}$, were studied in the gas phase and in solvents. Besides the SET studied for both electrondonating and -accepting pathways, the PL, the FHT and the RAF mechanisms were investigated for the most probable positions. In order to get insight into the RSA of the potent antioxidant, the PEPs of FHT (i.e. HAT or PCET) and RAF reactions between the Ir(III) complex and its free ligands with $\mathrm{HOO} \%$ $\mathrm{HO}^{*}$ radicals were selected to study in the gas phase at the same level of theory. Additional analyses at the TSs such as singly occupied molecular orbital (SOMO), Hirshfeld atomic spin density (ASD), NPA atomic charge as well as natural atomic orbital (NAO) occupancy for 1s orbital and natural electronic configuration (NEC) for the mitigating hydrogen as well as for the carbon and oxygen atoms involved in the reactions were helpful to clarify the hydrogen transfer mechanisms.

\section{Results and discussion}

\subsection{Synthesis and characterization}

The reaction scheme for the synthesis of the $\operatorname{Ir}($ III) complex is presented in Scheme 1, which involves in a revision of the synthetic procedure previously reported by Orwat and coworkers. ${ }^{38}$ Briefly, a microwave pressure reactor was used in a one-pot synthetic method for the complex formation. Reaction time and temperature were optimized for the synthesis of the Ir(III) complex based on the starting materials including

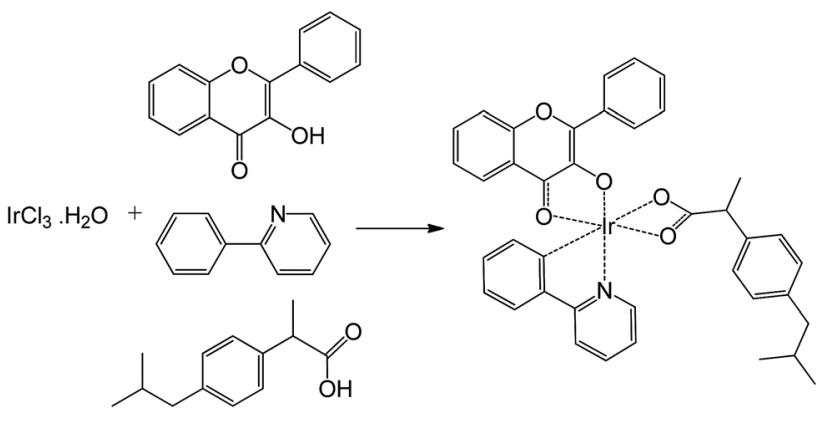

Scheme 1 Synthetic pathway of the $\operatorname{Ir}($ III) complex. Reagents and conditions: 2-ethoxyethanol/water $(2: 1, \mathrm{v} / \mathrm{v}), \mathrm{NaOH}$ (5 eq.), microwaves ( 5 bar, $350 \mathrm{~W}), 130^{\circ} \mathrm{C}, 45 \mathrm{~min}, 62.7 \%$.

a mixture of $\operatorname{IrCl}_{3} \cdot 3 \mathrm{H}_{2} \mathrm{O}$ and the three ligands in basic medium. Under the optimal conditions, i.e. $130{ }^{\circ} \mathrm{C}$ and $45 \mathrm{~min}$, the $\operatorname{Ir}(\mathrm{III})$ complex was obtained with a yield of $62.7 \%$. The complex was characterized by ${ }^{1} \mathrm{H}-\mathrm{NMR},{ }^{13} \mathrm{C}-\mathrm{NMR}$ and MS spectroscopies and elemental analyses.

The formation of the $\operatorname{Ir}(\mathrm{III})$ complex by coordinating the metal cation (Ir) to the ligands is confirmed by the ${ }^{1} \mathrm{H}-\mathrm{NMR}$ spectrum (Fig. S1 of the ESI $\dagger$ ) with the disappearance of the proton signals of $\mathrm{OH}$ and $\mathrm{COOH}$ groups of the starting flavonol and ibuprofen at $9.64 \mathrm{ppm}$ and $12.21 \mathrm{ppm}$, respectively. ${ }^{39-41}$ The signal of the $\alpha$ proton of the carbon coordinated to iridium (HC70, Fig. 1) is significantly shifted from about $7.60 \mathrm{ppm}$ in 2phenylpyridine in free form to $6.34 \mathrm{ppm}$ in the Ir(III) complex due to the formation of anionic charge of the cyclometalating phenyl ring. ${ }^{41}$ The ${ }^{13} \mathrm{C}$-NMR spectrum of the Ir(III) complex is in agreement with the proposed structure (Fig. S2 of the ESI $\dagger$ ). The mass spectrum of the Ir(III) complex showed a pattern with peaks centered at $\mathrm{m} / \mathrm{z}=790.2144$ in the positive region corresponding to $[\mathrm{M}+\mathrm{H}]^{+}$(Fig. S3 of the ESI $\dagger$ ).

\subsection{Structural and electronic properties by DFT}

The structure and the electronic properties of the $\operatorname{Ir}(\mathrm{III})$ complex and all ligands were studied by DFT. Optimized geometries of the Ir(III) complex at the B3LYP/Lanl2dz//6-31G(d) level of theory and all ligands at the B3LYP/6-31G(d) level of theory are shown in Fig. 1. The non-planar structure of 2-phenylpyridine is clearly observed with a dihedral angle HC80-C66-C61-N79 of about $-161^{\circ}$. The $\mathrm{B}$ ring of flavonol also rotates from the plane of the AC rings to form a dihedral angle O1-C5-C7-C12 of about $144^{\circ}$. For ibuprofen, the carboxylate group is found to be located at one side of the phenyl ring while all alkyl chains are located at the other side.

The structure of the $\operatorname{Ir}(\mathrm{III})$ complex was first optimized at various multiplicities $(1,3,5,7,9)$ in order to study its most likely spin states. As a result, the lowest energy structure was found for the singlet spin, which was kept for all following studies. As can be seen in Fig. 1, the Ir(III) cation coordinates to the three bidentate ligands through four $\mathrm{O}$ sites (i.e., two $\mathrm{O}$ atoms of flavonol and two $\mathrm{O}$ atoms of ibuprofen) and directly to C80 and N79 atoms of 2-phenylpyridine. The metal center adopts a non-symmetrical hexagonal configuration with atomic 


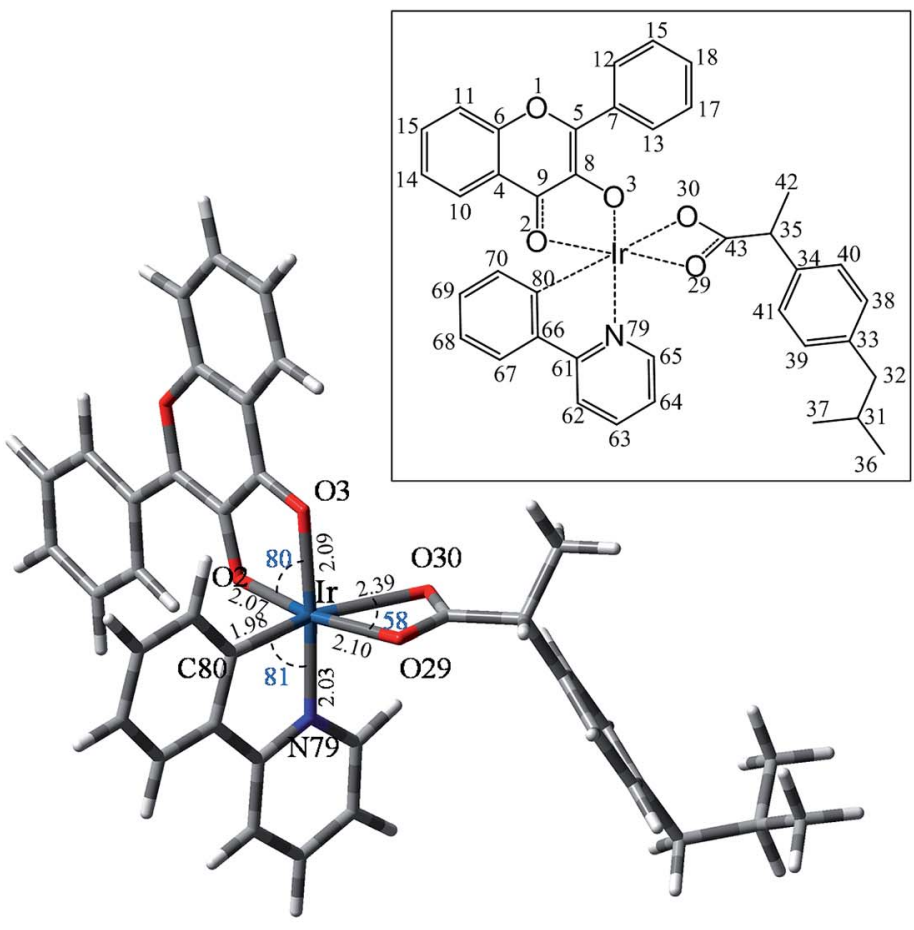

Ir (III) complex
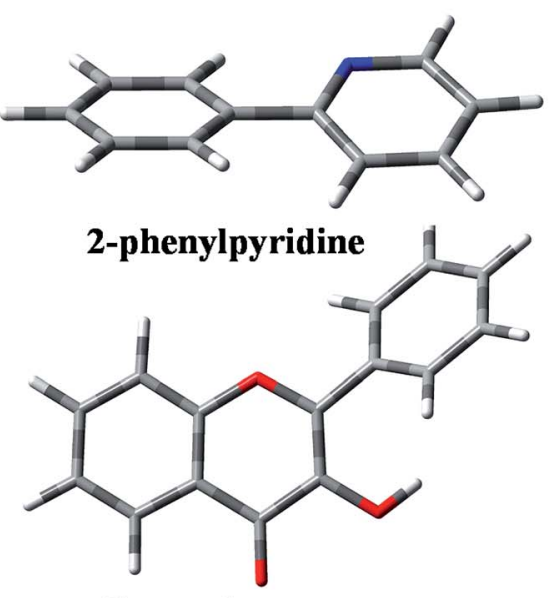

flavonol

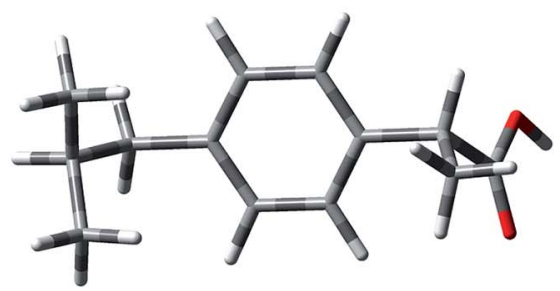

ibuprofen

Fig. 1 Optimized geometries of ligands at the B3LYP/6-31G(d) level of theory and of $\operatorname{rr}(I 11)$ complex at the B3LYP/Lanl2dz//6-31G(d) one. The inset shows the numbering of the 2D structure of the $\operatorname{Ir}($ III) complex.

distances from Ir to binding sites calculated as follows: Ir-O2 $(2.07 \AA), \mathrm{Ir}-\mathrm{O} 3(2.09 \AA)$, Ir-O29 (2.10 ̊), Ir-O30 (2.39 ̊), Ir-C80 $(1.98 \AA)$ and Ir-N79 (2.03 $\AA)$. Interestingly, in the complex structure, the flavonol and 2-phenylpyridine ligands adopt planar geometry, which favors the delocalization of electrons from the ligands to the central cation for the metal-ligand coordination. Cartesian coordinates and molecular enthalpies of the $\operatorname{Ir}($ III) complex are summarized in Table S1 of the ESI. $\dagger$

Mapping the ESP of a molecule allows one to predict the reactivity of a particular region of atoms toward nucleophilic or electrophilic attack. The ESP maps of the three ligands and Ir(III) complex are shown in the first column of Fig. 2, where the red regions represent the most negative ESPs and the blue ones display the most positive ESPs. Accordingly, the most negative electrostatic regions are found at the $\mathrm{N}$ and $\mathrm{C}$ of 2-phenylpyridine and at oxygen atoms of flavonol and ibuprofen ligands. These atoms are obviously the favorable sites that coordinate to the metal center for complex formation. For the $\operatorname{Ir}(\mathrm{III})$ complex, the most positive electrostatic region is found on the metal center (Ir) while the most negative one is located on the phenyl rings of 2-phenylpyridine and flavonol. This observation is confirmed by quantitative calculation of NPA atomic charges (Table S2 of the ESI $\dagger$ ).

Understanding the frontier molecular orbitals, particularly the highest occupied molecular orbital (HOMO) and the lowest unoccupied molecular orbital (LUMO), is important for predicting the electron-donating and electron-accepting capacities of a molecule. Fig. 2 shows the HOMO (middle column) and
LUMO (right column) of the three ligands and $\operatorname{Ir}(\mathrm{III})$ complex. It is observed that for all three ligands, the HOMOs and LUMOs are almost equally distributed across the molecular backbone. Nevertheless, for the Ir(III) complex, the HOMOs are mainly localized at the flavonol ligand and the LUMOs are delocalized more equally at both the 2-phenylpyridine and flavonol ligands. At the neutral state, the ibuprofen ligand does not contribute to the HOMO/LUMO of the Ir(III) complex. As expected, the HOMO is mostly contributed by 2-phenylpyridine and a small $\mathrm{d}$ part from metal ion while the LUMO is essentially contributed by the $\pi$-conjugate system of flavonol and 2-phenylpyridine ligands. The result is in agreement with the nature of metal-ligand $\left(\mathrm{e}^{-}\right.$ donor).

\subsection{Antioxidant properties by free radical scavenging activities}

The antioxidant properties of the complex and two of the ligands (ibuprofen and flavonol) were studied by RSA towards $\mathrm{HO}^{*}, \mathrm{NO}^{*}, \mathrm{DPPH}^{*}$ and $\mathrm{ABTS}^{\circ+}$. UV-visible and ESR spectroscopies were employed to follow the reactions. The results are summarized in Fig. 3 and Table 1.

3.3.1. DPPH' radical scavenging activity. Scavenging of the 2,2-diphenyl-1-picrylhydrazyl $\left(\mathrm{DPPH}^{\circ}\right)$ radical is among the most regularly used assays for evaluating antioxidant activity. This assay is based on the reduction of DPPH in methanol solution in the presence of a hydrogen-donating antioxidant which is measured at $517 \mathrm{~nm}$ wavelength as an indicator of 
A

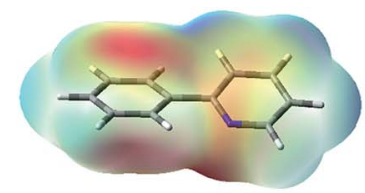

B

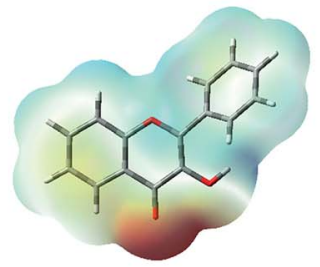

C

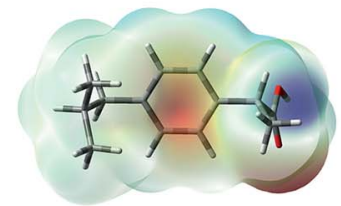

D

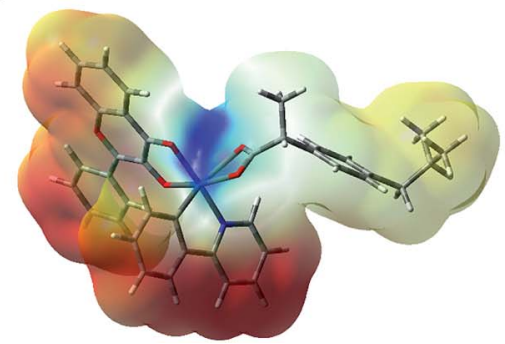

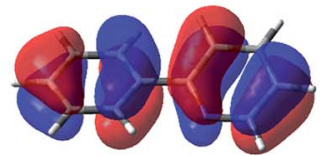
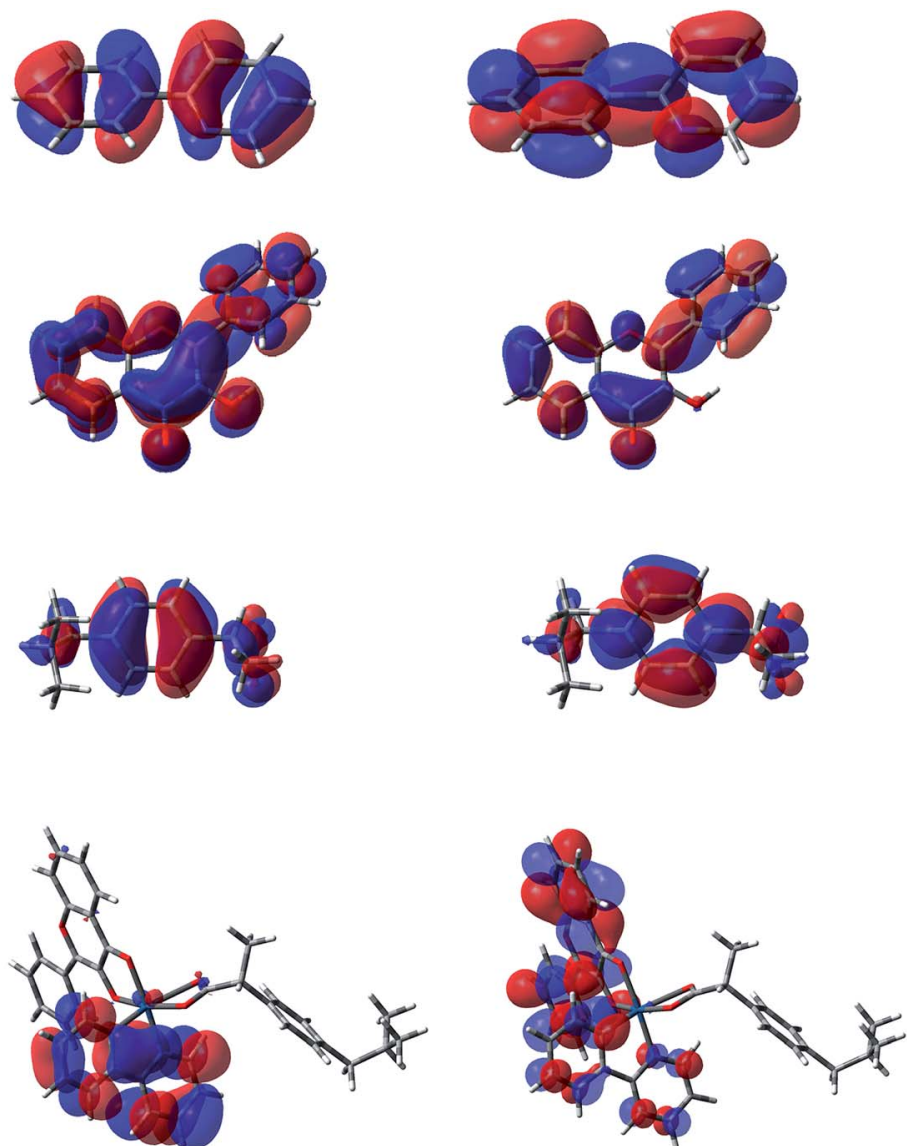

Fig. 2 Electrostatic potential maps (left), HOMO (middle) and LUMO (right) of (A) 2-phenylpyridine, (B) flavonol, (C) ibuprofen and (D) Ir(III) complex (isovalue $=0.02$ ).

antioxidant ability; the color of the solution changes from deep purple to yellow during the reduction. ${ }^{42,43}$

The antioxidant activity at various concentrations $(25,50$, 125 and $150 \mu \mathrm{M}$ ) of flavonol, ibuprofen, and the $\operatorname{Ir}(\mathrm{III})$ complex was determined by measuring the decolorization of $\mathrm{DPPH}^{\circ}$. The RSA increased with increasing concentration of the compounds. Flavonol, ibuprofen, Ir(III) complex, and ascorbic acid exhibited maximum activity of $62.45,45.15,98.95$ and $96.10 \%$, respectively, at $150 \mu \mathrm{M}$ concentration (Table S3 of the ESI $\dagger$ ). Under our reaction conditions, $\mathrm{IC}_{50}$ value of ascorbic acid was $14.25 \mu \mathrm{M}$, while $\mathrm{IC}_{50}$ values for flavonol, ibuprofen, and $\operatorname{Ir}(\mathrm{III})$ complex were as $85.32,143.55$ and $8.32 \mu \mathrm{M}$, respectively (Table 1). The RSA can be classified in the following order: $\operatorname{Ir}(\mathrm{III})$ complex $>$ ascorbic acid $>$ flavonol $>$ ibuprofen.

By ESR spectroscopy, the $\operatorname{Ir}($ III) complex displayed significant DPPH $^{*}$ RSA in a dose-dependent manner (Fig. 3). The radical scavenging activity of the $\operatorname{Ir}(\mathrm{III})$ complex increased with increasing concentration, which presented as $37.86 \%$ and $98.27 \%$ (calculated from the ESR signal intensity, Fig. S5 of the ESI $\dagger$ ) at $25 \mu \mathrm{M}$ and $150 \mu \mathrm{M}$ in comparison with $25.73 \%$ and $96.46 \%$ for ascorbic acid at the same concentrations, respectively. The scavenging activities of the DPPH' radicals obtained by ESR spectroscopy are in the same order as that of UV-visible spectroscopic study: $\operatorname{Ir}(\mathrm{III})$ complex $>$ ascorbic acid $>$ flavonol $>$ ibuprofen.
3.3.2. HO' radical scavenging activity. The hydroxyl radical $\left(\mathrm{HO}^{\circ}\right)$ is one of the most dangerous species to organisms and the environment compared to other free radicals due to its potent oxidizing ability. It attacks proteins, DNA, polyunsaturated fatty acids in membranes and react rapidly with the surrounding chemicals containing organic pollutants and inhibitors. ${ }^{44,45}$ Hence, the scavenging of this radical is one of the main goals of antioxidant studies. The results of $\mathrm{OH}^{*}$ scavenging by various concentrations $(25,50,125$ and $150 \mu \mathrm{M})$ of flavonol, ibuprofen, Ir(III) complex, and ascorbic acid are given in Table S4 of the ESI. $\uparrow$ Flavonol, ibuprofen, $\operatorname{Ir}(\mathrm{III})$ complex and ascorbic acid exhibited maximum activity of 53.18, 58.17, 92.35 and $78.21 \%$, respectively, at $150 \mu \mathrm{M}$ concentration. The $\mathrm{IC}_{50}$ value of ascorbic acid was $28.12 \mu \mathrm{M}$, while $\mathrm{IC}_{50}$ values for flavonol, ibuprofen and $\operatorname{Ir}($ III) complex were 138.24, 105.23 and $19.32 \mu \mathrm{M}$, respectively (Table 1). As a result, the HO ${ }^{\circ}$ RSA decreased in the following order: $\operatorname{Ir}(\mathrm{III})$ complex $>$ ascorbic acid $>$ flavonol $>$ ibuprofen.

In ESR monitoring, $\mathrm{HO}^{*}$ radicals generated in $\mathrm{Fe}^{2+} / \mathrm{H}_{2} \mathrm{O}_{2}$ system are trapped by DMPO forming spin adduct and detected by an ESR spectrometer. Ascorbic acid was used as positive control. The Ir(III) complex displayed significant HO` RSA with increasing concentration (Fig. S6 of the ESI $\dagger$ ). The ESR results show that the Ir(III) complex and ascorbic acid suppress about 

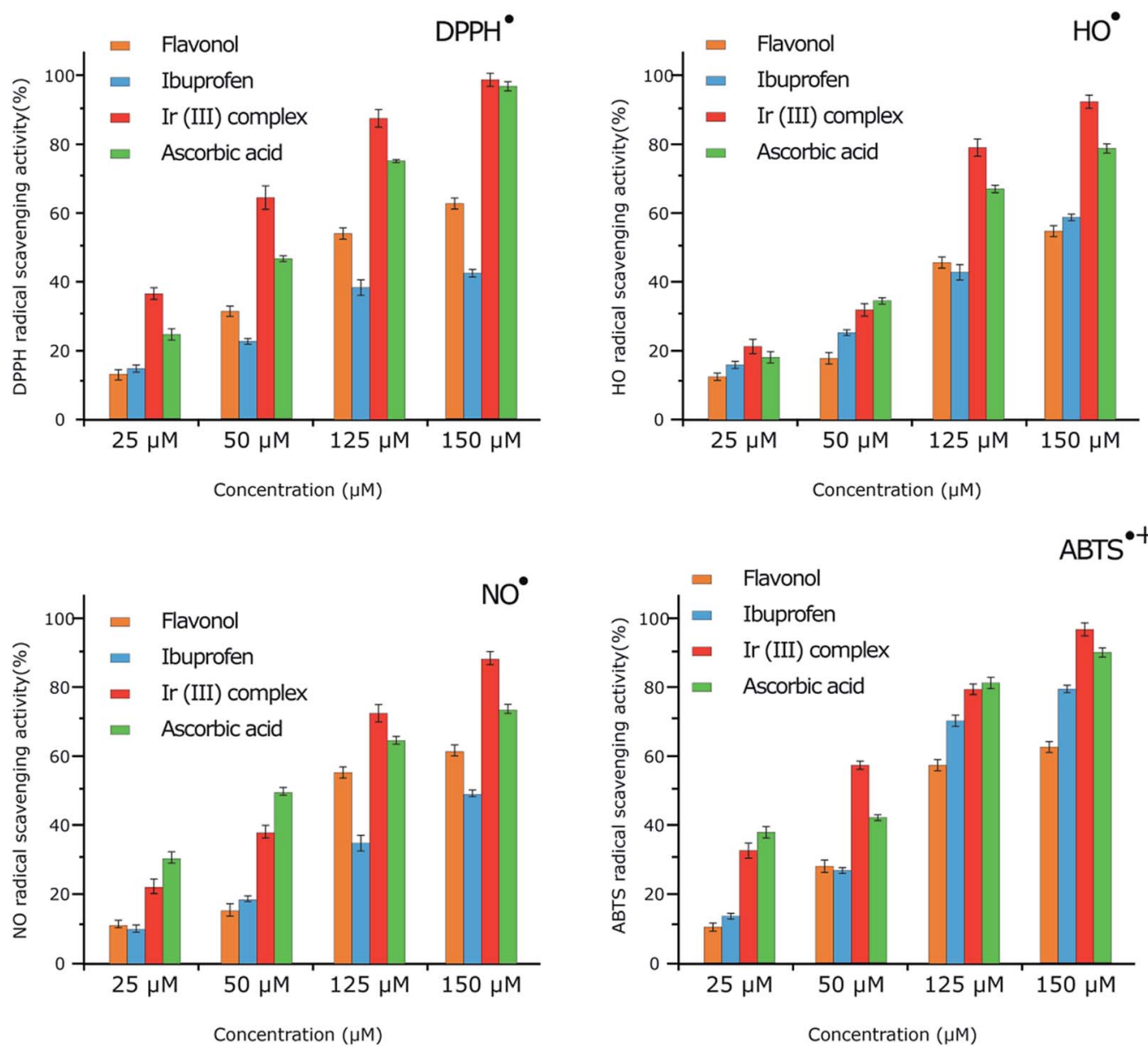

Fig. 3 Free radical scavenging activity towards $\mathrm{DPPH}^{\circ}, \mathrm{HO} \mathrm{N}^{\circ}, \mathrm{NO}{ }^{*}$ and $\mathrm{ABTS}^{\circ+}$ presented according to ESR results. The mean $\pm \mathrm{SD}$ is shown for triplicate experiments.

92.12\% and $78.64 \%$ (calculated from the ESR signal intensity, Fig. 3) of the hydroxyl radicals at $150 \mu \mathrm{M}$, respectively. The order of potent antioxidant activity was found to be identical to that obtained from UV-visible spectroscopy.

3.3.3. NO' radical scavenging activity. In the $\mathrm{NO}^{*}$ scavenging study by UV-visible spectroscopy, nitric oxide produced from sodium nitroprusside reacts with oxygen to form nitrite. A potent antioxidant inhibits nitrite formation by competing with oxygen to react with nitric oxide. ${ }^{46}$ The nitrite ion in aqueous solution reacts with sulphanilamide present in the Griess reagent to form diazotized molecule to detect spectrophotometrically at $546 \mathrm{~nm}$. The nitric oxide scavenging ability of flavonol, ibuprofen, Ir(III) complex, and ascorbic acid in various concentrations $(25,50,125$ and $150 \mu \mathrm{M})$ is given in Table S5 of the ESI. $\dagger$ Flavonol, ibuprofen, Ir(III) complex and ascorbic acid presented maximum activity of $62.32 \%, 49.21 \%, 89.20 \%$, and $73.31 \%$ respectively at $150 \mu \mathrm{M}$ concentration. The $\mathrm{IC}_{50}$ value of ascorbic acid was $43.27 \mu \mathrm{M}$, while $\mathrm{IC}_{50}$ values for flavonol,

Table 1 Free radical scavenging activity of flavonol, ibuprofen, Ir(III) complex and ascorbic acid as standard reference towards $\mathrm{HO}^{\circ}, \mathrm{NO}^{\circ}$, DPPH${ }^{\circ}$ and $\mathrm{ABTS}^{++}$

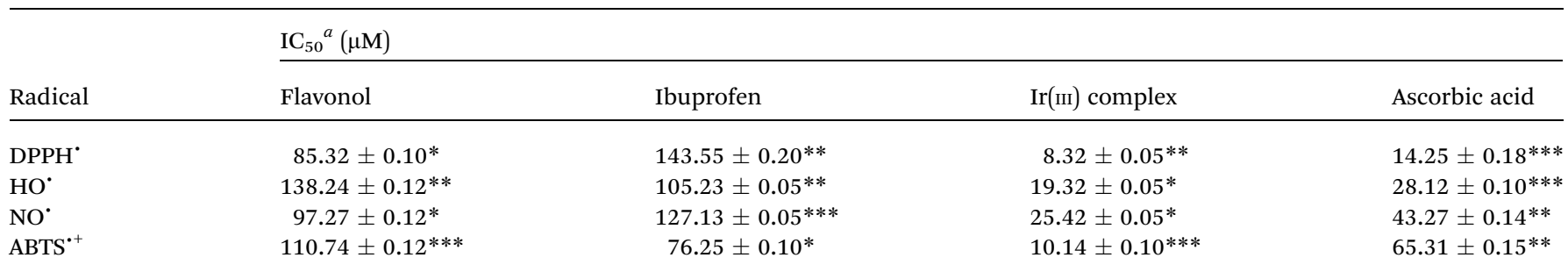

${ }^{a}$ All values are the means of three measurements and given as mean \pm SD. Statistically significant differences are indicated by asterisks $(* * * p<$ $0.001, * * p<0.01, * p<0.05$ compared to ascorbic acid). 
ibuprofen, and $\operatorname{Ir}(\mathrm{III})$ complex were 97.27, 127.13 and $25.42 \mu \mathrm{M}$, respectively (Table 1). Among the test compounds, the $\operatorname{Ir}(\mathrm{III})$ complex showed the most potent $\mathrm{NO}^{*} \mathrm{RSA}$, which decreased in the following order: $\operatorname{Ir}($ III) complex $>$ ascorbic acid $>$ flavonol $>$ ibuprofen.

Furthermore, antioxidant activities of flavonol, ibuprofen, Ir(III) complex and ascorbic acid were also investigated for NO${ }^{*}$ radical scavenging by ESR spectroscopy. NO ${ }^{*}$ radical was released from a nitric oxide donor, $S$-nitroso- $N$-acetylpenicillamine. $\mathrm{NO}^{\circ}$ was trapped with iron-dithiocarbamate to produce the $\left[(\mathrm{MGD})_{2}-\mathrm{Fe}^{2+}-\mathrm{NO}\right]$ adduct which gave a triplet-line ESR signal (Fig. S7 of the ESI $\dagger$ ). Hemoglobin, as positive control, inhibited the ESR signal that indicated the production of this spin adduct from NO ${ }^{*}$. The $\operatorname{Ir}(\mathrm{III})$ complex displayed significant scavenging activity towards $\mathrm{NO}^{*}$ when increasing the concentration. The ESR results show that the Ir(III) complex and ascorbic acid suppress about $88.87 \%$ and $72.35 \%$ (calculated from the ESR signal intensity, Fig. 3) of the NO` radicals at 150 $\mu \mathrm{M}$, respectively. Antioxidant activity decreases in the following order: $\operatorname{Ir}(\mathrm{III})$ complex $>$ ascorbic acid $>$ flavonol > ibuprofen, similar to the results of UV-visible spectroscopic study.

3.3.4. ABTS $^{\cdot+}$ radical scavenging activity. 2,2'-Azino-bis(3ethylbenzothiazoline-6-sulphonic acid) $\left(\mathrm{ABTS}^{\circ+}\right)$, forming a relatively stable radical (ABTS*) upon one-electron oxidation, has become a popular substrate to evaluate antioxidant capacity. The blue ABTS $^{{ }^{+}}$radical cation becomes colorless on reduction which absorbs light at $734 \mathrm{~nm}$ wavelength. ${ }^{47}$ The ABTS $^{*+}$ RSA of flavonol, ibuprofen, Ir(III) complex, and ascorbic acid in various concentrations (25, 50, 125 and 150 $\mu \mathrm{M})$ is given in Table S6 of the ESI. $\dagger$ At $150 \mu \mathrm{M}$, flavonol, ibuprofen, Ir(III) complex and ascorbic acid presented maximum activity of $62.84,80.18,96.12$ and $89.27 \%$, respectively. The $\mathrm{IC}_{50}$ value of ascorbic acid was $65.31 \mu \mathrm{M}$, while $\mathrm{IC}_{50}$ values for flavonol, ibuprofen, and $\operatorname{Ir}(\mathrm{III})$ complex were $110.74,76.25$ and $10.14 \mu \mathrm{M}$, respectively (Table 1 ). The Ir(III) complex showed the most potent ABTS $^{*+}$ RSA, which decreased in the following order: $\operatorname{Ir}(\mathrm{III})$ complex $>$ ascorbic acid $>$ flavonol $>$ ibuprofen.

In addition, antioxidant activities of flavonol, ibuprofen, Ir(III) complex and ascorbic acid were also considered for ABTS ${ }^{+}$ radical scavenging by ESR. The Ir(III) complex presents considerable $\mathrm{ABTS}^{-+}$RSA with increasing concentration (Fig. S8 of the ESI $\dagger$ ). The ESR results confirmed that Ir(III) complex and ascorbic acid suppress about 95.94\% and 89.72\% (calculated from the ESR signal intensity, Fig. 3) of $\mathrm{ABTS}^{\circ+}$ at $150 \mu \mathrm{M}$, respectively. Antioxidant activity decreases in the following order: Ir(III) complex > ascorbic acid > flavonol > ibuprofen, similar to the results of UV-visible spectroscopic study.

Firstly, the scavenging activities of $\mathrm{DPPH}^{\circ}, \mathrm{OH}^{*}, \mathrm{NO}^{*}$ and $\mathrm{ABTS}^{{ }^{+}}$radicals obtained by ESR spectroscopy are in excellent agreement with the results obtained from UV-visible spectroscopy. Secondly, the antioxidant activity results of the free ligands and $\operatorname{Ir}(\mathrm{III})$ complex against the free radicals $\mathrm{DPPH}^{*}, \mathrm{OH}^{*}$, $\mathrm{NO}^{\bullet}$ and $\mathrm{ABTS}^{*+}$ showed that the $\mathrm{Ir}(\mathrm{III})$ complex displays greater scavenging activity than the free ligands and also the standard antioxidant ascorbic acid, with decreasing order as follows:
Ir(III) complex $>$ ascorbic acid $>$ flavonol $>$ ibuprofen. Thirdly, the antioxidant activity of the Ir(III) complex against the DPPH radical is better than that against the other radicals and the trend is decreasing in the following order: $\mathrm{DPPH}^{*}>\mathrm{ABTS}^{{ }^{+}}>$ $\mathrm{OH}^{*}>\mathrm{NO}^{*}$. In the following part, we choose to discuss in more detail the mechanism of $\mathrm{DPPH}^{*}$ scavenging activity by the $\operatorname{Ir}(\mathrm{III})$ complex.

3.3.5. Mechanism of DPPH ${ }^{\bullet}$ radical scavenging by the $\operatorname{Ir}(\mathrm{III})$ complex. The scavenging mechanism of $\mathrm{DPPH}^{*}$ by the $\operatorname{Ir}(\mathrm{III})$ complex is studied in detail due to the high radical scavenging activity of this complex towards $\mathrm{DPPH}^{\circ}$ in comparison to the other radicals. UV-visible spectra were recorded after mixing solutions of $\mathrm{DPPH}^{*}(50 \mu \mathrm{M})$ and $\mathrm{Ir}(\mathrm{III})$ complex (10-60 $\mu \mathrm{M}$ ) in methanol : PBS (1:9) solutions ( $\mathrm{pH}$ 7.4) (Fig. 4). On increasing the concentration of the $\operatorname{Ir}($ III) complex, we simultaneously observed the decreasing of the absorption band of $\mathrm{DPPH}^{*}$ form $(518 \mathrm{~nm})$ and the increasing of the absorption band of $\mathrm{DPPH}^{-}$anion (around $425 \mathrm{~nm}$ ). This observation shows the consumption of the $\mathrm{DPPH}^{\circ}$ present in the reaction to produce the $\mathrm{DPPH}^{-}$anion form. ${ }^{48}$ The $425 \mathrm{~nm}$ absorption bands were maximized at $40 \mu \mathrm{M}$ then decreased upon increasing the concentration of the $\operatorname{Ir}(\mathrm{III})$ complex to 50 or $60 \mu \mathrm{M}$ due to the exchange of the anion form of $\mathrm{DPPH}^{-}$to DPPH-H. The DPPH-H molecule was formed as a result of accepting one proton from the $\operatorname{Ir}(\mathrm{III})$ complex. The result is totally in agreement with our recent findings for a $\mathrm{Cu}$ (II) complex and others. ${ }^{49-51}$

Furthermore, in the preliminary phase of another study, we also investigated the in vitro antitumor activity of the $\operatorname{Ir}(\mathrm{III})$ complex and two of the ligands towards A549, A2780 and A2780cis cells in comparison with cis-platin as reference. From the results, the studied complex shows considerably higher activity than free ligands and cis-platin (Table S7 and Fig. S9 of the ESI $\dagger$ ). This excellent cytotoxicity of the $\operatorname{Ir}(\mathrm{III})$ complex seems to relate to its ability of ROS production (Fig. S10 of the ESI $\dagger$ ).

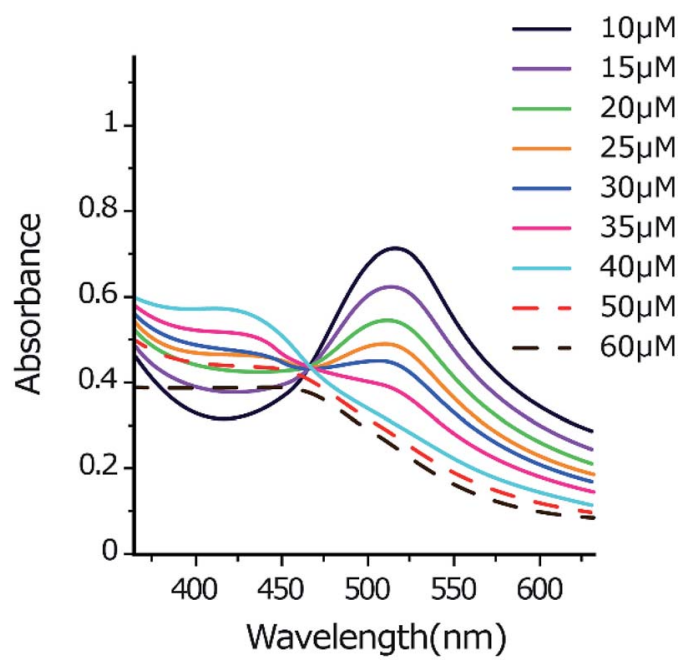

Fig. 4 UV-visible spectra monitoring the reaction between $\mathrm{DPPH}^{*}(50$ $\mu \mathrm{M})$ and $\operatorname{Ir}(\mathrm{II})$ complex $(10-60 \mu \mathrm{M})$ in methanol: PBS (1:9) solutions $(\mathrm{pH} 7.4)$. 
Table 2 Lowest BDE, lowest PA and IP/EA values calculated in the gas phase and in water and PEA solvent for three ligands and Ir(III) complex

\begin{tabular}{|c|c|c|c|c|c|c|c|c|c|c|c|c|c|}
\hline \multirow{2}{*}{$\begin{array}{l}\text { Properties (kcal } \\
\mathrm{mol}^{-1} \text { ) }\end{array}$} & \multirow[b]{2}{*}{ Bond position } & \multicolumn{3}{|c|}{ 2-Phenylpyridine ${ }^{a}$} & \multicolumn{3}{|c|}{ Flavonol $^{a}$} & \multicolumn{3}{|c|}{ Ibuprofen $^{a}$} & \multicolumn{3}{|l|}{$\operatorname{Ir}(\mathrm{III}) \operatorname{complex}^{b}$} \\
\hline & & Gas & Water & PEA & Gas & Water & PEA & Gas & Water & PEA & Gas & Water & PEA \\
\hline & $\mathrm{C} 13-\mathrm{H}$ & & & & 105.9 & 106.4 & & & & & - & - & \\
\hline & $\mathrm{C} 17-\mathrm{H}$ & & & & 111.0 & & & & & & - & - & \\
\hline & $\mathrm{C} 31-\mathrm{H}$ & & & & & & & 92.2 & & & 97.0 & - & \\
\hline & C62-H & 108.8 & & & & & & & & & - & - & \\
\hline & $\mathrm{C} 65-\mathrm{H}$ & 104.7 & 104.9 & 102.0 & & & & & & & - & - & \\
\hline & $\mathrm{C} 67-\mathrm{H}$ & 108.8 & & & & & & & & & - & - & \\
\hline \multirow[t]{3}{*}{ PA (ETE) } & C8-O-H & & & & 335.1 & & & & & & - & & \\
\hline & $\mathrm{C} 13-\mathrm{H}$ & & & & 335.1 & 105.2 & 276.7 & & & & 401.7 & 110.6 & \\
\hline & $\mathrm{C} 31-\mathrm{H}$ & & & & & & & 348.9 & 125.8 & & 406.1 & 126.1 & \\
\hline IP (PDE) & & 179.5 & 156.2 & 151.5 & 170.1 & 149.1 & 142.3 & 183.4 & 160.2 & 153.8 & $136.4(291.5)$ & $130.5(35.2)$ & 119.8 \\
\hline $\mathrm{EA}$ & & -5.9 & 54.1 & 24.9 & 12.7 & 68.3 & 41.7 & -22.5 & 35.8 & 8.4 & 26.8 & 79.3 & 52.1 \\
\hline
\end{tabular}

\subsection{Intrinsic reactivity by DFT}

The principal intrinsic reactivities characteristic for the antioxidant properties of a molecule such as the $\mathrm{H}$-atom donor (lowest BDEs only), the proton donor (lowest PAs only), the electron donor (IP) and electron acceptor (EA) capacities of all compounds are presented in Table 2. Calculations were performed in the gas phase and in water and PEA solvent (IEFPCM) at the B3LYP/6-31G(d) and the B3LYP/Lanl2dz//6-31G(d) levels of theory for ligands and Ir(III) complex, respectively.

3.4.1. Bond dissociation enthalpy. The BDE characterizes the H-donating capacity of an antioxidant molecule which is known as the HAT mechanism. BDE values of all $\mathrm{C}-\mathrm{H}$ and $\mathrm{O}-\mathrm{H}$ bonds of all compounds were calculated; the lower the BDE the greater the antioxidant activity of the molecule.

As seen in Table 2, in the gas phase, the lowest BDE value found for free ligands is at the $\mathrm{C} 8-\mathrm{O}-\mathrm{H}$ position on flavonol $\left(69.2 \mathrm{kcal} \mathrm{mol}^{-1}\right)$. Ibuprofen shows smallest BDE value for the $\mathrm{C}-\mathrm{H}$ bond located between the carboxylic groups and the phenyl ring, i.e. $\mathrm{C} 35-\mathrm{H}\left(78.9 \mathrm{kcal} \mathrm{mol}^{-1}\right)$, followed by the para $\mathrm{C}-\mathrm{H}$ position next to the phenyl rings, i.e. $\mathrm{C} 32-\mathrm{H}\left(87.1 \mathrm{kcal} \mathrm{mol}^{-1}\right)$. The H-donating capacity of these positions results from the electron-withdrawing effect of the carboxylic groups and the conjugated $\pi$-system of the phenyl ring. In contrast, almost all of the $\mathrm{H}$ atoms of 2-phenylpyridine and flavonol (except for C8$\mathrm{O}-\mathrm{H}$ ) are directly linked to the $\mathrm{C}$ atoms of the conjugated $\pi$ system and show much higher BDEs; the lowest values stand at around 105-110 kcal mol${ }^{-1}$. For the Ir(III) complex, the lowest $\mathrm{BDE}$ values are also found on the same $\mathrm{C}-\mathrm{H}$ positions of the easy-to-break ibuprofen ligand. We observe nearly identical BDEs for $\mathrm{C} 35-\mathrm{H}$ and $\mathrm{C} 32-\mathrm{H}$ of the complex as well as of the ibuprofen ligand (78.7 and $87.2 \mathrm{kcal} \mathrm{mol}^{-1}$ in the gas phase for C35 and C32 positions, respectively). The H-atom donating capacity decreases as follows: flavonol $>\operatorname{Ir}($ III) complex $\approx$ ibuprofen $>2$-phenylpyridine. Both the Ir(III) complex and two ligands demonstrate strong antioxidant capacity through the $\mathrm{H}$ donating mechanism which is higher than that of phenol (BDE of O-H: $\left.88.3 \pm 0.8 \mathrm{kcal} \mathrm{mol}^{-1}\right){ }^{52}$

There is almost no effect on the BDE values of all compounds in water and in PEA. For example, we observed for $\mathrm{C} 35-\mathrm{H}$ of ibuprofen BDE values of $79.4 \mathrm{kcal} \mathrm{mol}^{-1}$ and $78.6 \mathrm{kcal} \mathrm{mol}^{-1}$, and for $\mathrm{C} 8-\mathrm{O}-\mathrm{H}$ of flavonol BDE values of 69.6 and 69.4 kcal $\mathrm{mol}^{-1}$ in water and in PEA, respectively. Similarly, a BDE value of $79.3 \mathrm{kcal} \mathrm{mol}^{-1}$ in water $v s .78 .3 \mathrm{kcal} \mathrm{mol}^{-1}$ in PEA was found for the $\operatorname{Ir}($ III) complex.

3.4.2. Proton affinity. The PL reaction ((R2), ESI $\dagger$ ) is characterized by the PA: the lower the PA, the higher the protondonating capacity of the molecule (Table 2).

In the gas phase, flavonol exhibits the best proton-donating capacity among the three ligands; the lowest PA values were found equal at $335.1 \mathrm{kcal} \mathrm{mol}^{-1}$ for $\mathrm{C} 13-\mathrm{H}$ and $\mathrm{C} 8-\mathrm{O}-\mathrm{H}$. Ibuprofen shows the lowest PA values for the $\mathrm{C} 31-\mathrm{H}$ and $\mathrm{C} 35-\mathrm{H}$ positions, at 348.9 and $360.8 \mathrm{kcal} \mathrm{mol}^{-1}$, respectively. 2-Phenylpyridine displays lowest PA values for $\mathrm{C} 62-\mathrm{H}, \mathrm{C} 63-\mathrm{H}$, and $\mathrm{C} 64-\mathrm{H}$, at an average of about $50 \mathrm{kcal} \mathrm{mol}^{-1}$ higher than that of the other ligands. For the Ir(III) complex, the lowest PA is found at $\mathrm{C} 35-\mathrm{H}$, being $355.5 \mathrm{kcal} \mathrm{mol}^{-1}$. The proton-donating capacity in the gas phase decreases as follows: flavonol $>$ ibuprofen $>$ Ir(III) complex > 2-phenylpyridine.

Interestingly, in water, we observed much lower PA values for all compounds than in the gas phase, by a factor of from 3 to 5 times. For example, in water, the lowest PA found for $\mathrm{C} 35-\mathrm{H}$ of the Ir(III) complex (72.1 kcal mol ${ }^{-1}$ ) and for the same bond of ibuprofen (73.5 kcal mol $\mathrm{m}^{-1}$ ) are all about five times lower than in the gas phase. In the non-polar solvent (PEA), the PA value of 
the Ir(III) complex rises to $242.3 \mathrm{kcal} \mathrm{mol}^{-1}$ for the same bond (C35-H).

This result indicates that the solvent, especially a polar solvent, has an important impact on promoting solvation of molecules and the deprotonation process. In water, the protondonating capacity decreases in the order: $\operatorname{Ir}(\mathrm{III})$ complex $\approx$ ibuprofen $>$ flavonol $\approx 2$-phenylpyridine. Proton loss occurs even more conveniently than the hydrogen abstraction mechanism in polar solvent (lowest PA values < lowest BDE values). Similar phenomena of decreasing of PA values in polar solvents have been previously reported. ${ }^{52}$ However, if we take into account the ETE value $\left(78.4 \mathrm{kcal} \mathrm{mol}^{-1}\right)$ of the second step of the SPLET mechanism, i.e. electron transfer from the radical anion resulting from deprotonation at the $\mathrm{C} 35-\mathrm{H}$ position of the Ir(III) complex, the total energy for transferring the whole package of proton and electron in water is considerably higher than the $\mathrm{BDE}$ value, $150.5 \mathrm{kcal} \mathrm{mol}^{-1}$ compared to $79.3 \mathrm{kcal} \mathrm{mol}^{-1}$. Thus, for the $\operatorname{Ir}(\mathrm{III})$ complex the SPLET mechanism is less favorable than the FHT one in terms of the intrinsic properties.

3.4.3. Ionization potential and electron affinity. The SET mechanism is initiated by one electron-donating reaction ((R3), $\mathrm{ESI} \dagger)$ or one electron-accepting one ((R4), ESI $\dagger)$. This mechanism is respectively characterized by the IP and the EA, calculated based on the corresponding reactions (eqn (3) and (4), ESI $\dagger$ ). The lower the IP and/or the higher the EA value, the greater the antioxidant activity of the molecule. IP and EA calculated in the gas phase and in the two solvents are shown in Table 2.

One may notice that the IP values for all ligands in the gas phase are quite similar (about 170-180 kcal mol ${ }^{-1}$ ) and considerably higher than the IP of the Ir(III) complex (136.4 $\left.\mathrm{kcal} \mathrm{mol}^{-1}\right)$. In comparison with the IP value of the standard phenol (about $185 \mathrm{kcal} \mathrm{mol}^{-1}$ ), ${ }^{53}$ the result indicates that the Ir(III) complex can act as a good electron donor molecule and better than all the ligands. In water, these values were reduced to $130.5 \mathrm{kcal} \mathrm{mol}^{-1}$ for the $\operatorname{Ir}(\mathrm{III})$ complex, $149.1 \mathrm{kcal} \mathrm{mol}{ }^{-1}$ for flavonol and $160.2 \mathrm{kcal} \mathrm{mol}^{-1}$ for ibuprofen. In PEA, the IP value of the Ir(III) complex even decreases to $119.8 \mathrm{kcal} \mathrm{mol}^{-1}$. The electron donor capacity of molecules was clearly favored in solvent compared to the gas phase, especially in non-polar solvent, and it decreased in the following order: $\operatorname{Ir}($ III) complex $>$ flavonol > 2-phenylpyridine > ibuprofen.

In the gas phase, the electron acceptor capacity of all compounds could be classified as being in the order $\operatorname{Ir}(\mathrm{III})$ complex $\left(26.8 \mathrm{kcal} \mathrm{mol}^{-1}\right)>$ flavonol $\left(12.7 \mathrm{kcal} \mathrm{mol}^{-1}\right)>2$ phenylpyridine $\left(-5.9 \mathrm{kcal} \mathrm{mol}^{-1}\right)>$ ibuprofen $\left(-22.5 \mathrm{kcal} \mathrm{mol}^{-1}\right)$. This order, though unchanged in water, but with higher values than in the gas phase, e.g. $79.3 \mathrm{vs}$. $26.8 \mathrm{kcal} \mathrm{mol}^{-1}$ for the $\mathrm{Ir}(\mathrm{III})$ complex in water $v s$. in the gas phase, indicates that the electron-accepting mechanism is more favored in polar solvent than in vacuo. The Ir(III) complex is evidently the best electron donor and electron acceptor compared to its ligands.

Furthermore, the PDE value characterizing the second step of the SETPT mechanism ((R5), eqn (5) in the ESI $\dagger$ ) for the radical cation of the $\operatorname{Ir}($ III) complex was also calculated. The obtained PDEs in the gas phase and in water are 291.5 and $35.2 \mathrm{kcal} \mathrm{mol}^{-1}$, respectively. Thus, it is observed that the SETPT mechanism is less favored than the FHT one in terms of the intrinsic properties.

Overall, we note that the $\operatorname{Ir}($ III) complex is a good antioxidant and its capacity of giving a hydrogen atom or donating or accepting one electron are all better than those of the ligands. The results in the next part obtained by RSA confirm the superior antioxidant properties of Ir(III) complex compared to its ligands.

\subsection{Thermochemical properties and kinetics of the reaction by DFT}

The consideration of the influence of reactive media as well as chemical nature of the free radicals provides a more complete picture of the scavenging reaction. For that reason, we evaluate in this section the thermochemical properties (enthalpy and Gibbs free energy) of reactions of the Ir(III) complex and free ligands with $\mathrm{HO}^{\circ}, \mathrm{HOO}^{\circ}, \mathrm{NO}^{\circ}, \mathrm{DPPH}^{\circ}$ and $\mathrm{ABTS}^{\circ+}$ radicals in the gas phase, in water and in PEA. The $\mathrm{HO}^{\circ}$ and $\mathrm{HOO}^{\circ}$ radicals are the most common radicals found in living bodies, whereas NO', $\mathrm{DPPH}^{\circ}$ and $\mathrm{ABTS}^{\circ+}$ are the ones used in the experimental antioxidant essays. Five antioxidant mechanisms including SET, PL, FHT (HAT/PCET) and RAF are evaluated in detail.

The thermochemical property results for the complex are all presented in Table 3. The data obtained for the ligands can be found in Tables S8 and S9 of the ESI. $\dagger$ As can be seen in Table 3, the RAF reaction with $\mathrm{DPPH}^{*}$ radical was not performed because of the steric effect of the radical, whereas only the SET mechanism was taken into account for the $\mathrm{ABTS}^{\cdot+}$ radical due to the electron transfer process of the antioxidant assays.

In addition, the PEPs of FHT (HAT or PCET) and RAF of the studied compounds with $\mathrm{HO}^{\circ}$ and $\mathrm{HOO}^{\circ}$ radicals are also established in order to provide more insight into the free radical scavenging mechanism.

3.5.1. Single electron transfer reaction. The electrondonating reaction (R1) and electron-accepting reaction (R2) were studied of the Ir(III) complex and two ligands with different free radicals such as $\mathrm{HO}^{\circ}, \mathrm{HOO}^{\circ}, \mathrm{NO}^{\circ}$, $\mathrm{DPPH}^{*}$ and $\mathrm{ABTS}^{\circ}$ :

$$
\begin{aligned}
& \text { Anti-ox }+\left(\mathrm{R}^{\bullet}\right) \rightarrow\left(\text { Anti-ox }^{\cdot+}\right)+\left(\mathrm{R}^{-}\right) \\
& \Delta H^{0}=H\left(\text { Anti-ox }^{\cdot+}\right)+H\left(\mathrm{R}^{-}\right)-H(\text { Anti-ox })-H\left(\mathrm{R}^{\cdot}\right) \\
& \Delta G^{0}=G\left(\text { Anti-ox }^{\cdot+}\right)+G\left(\mathrm{R}^{-}\right)-G(\text { Anti-ox })-G\left(\mathrm{R}^{\bullet}\right) \\
& \text { Anti-ox }+\left(\mathrm{R}^{\cdot}\right) \rightarrow\left(\text { Anti-ox }{ }^{\cdot-}\right)+\left(\mathrm{R}^{+}\right) \\
& \Delta H^{0}=H\left(\text { Anti-ox }^{\cdot-}\right)+H\left(\mathrm{R}^{+}\right)-H(\text { Anti-ox })-H\left(\mathrm{R}^{\cdot}\right) \\
& \Delta G^{0}=G\left(\text { Anti-ox }^{\cdot-}\right)+G\left(\mathrm{R}^{+}\right)-G(\text { Anti-ox })-G\left(\mathrm{R}^{\bullet}\right)
\end{aligned}
$$

The reaction enthalpies $\left(\Delta H^{0}\right)$ and Gibbs free energies $\left(\Delta G^{0}\right)$ of reactions (R1) and (R2) for the Ir(III) complex are calculated in the gas phase and in solvents at $298.15 \mathrm{~K}$ as indicated by eqn (1)-(4). Values are presented in Table 3. The corresponding results for the ligands are shown in Tables S8 and S9 of the ESI. $\dagger$ 
Table 3 Enthalpy $\left(\Delta H^{0}\right)$ and Gibbs free energy $\left(\Delta G^{0}\right)$ of the principal reactions for free radical scavenging by $\operatorname{Ir}(I I I)$ complex

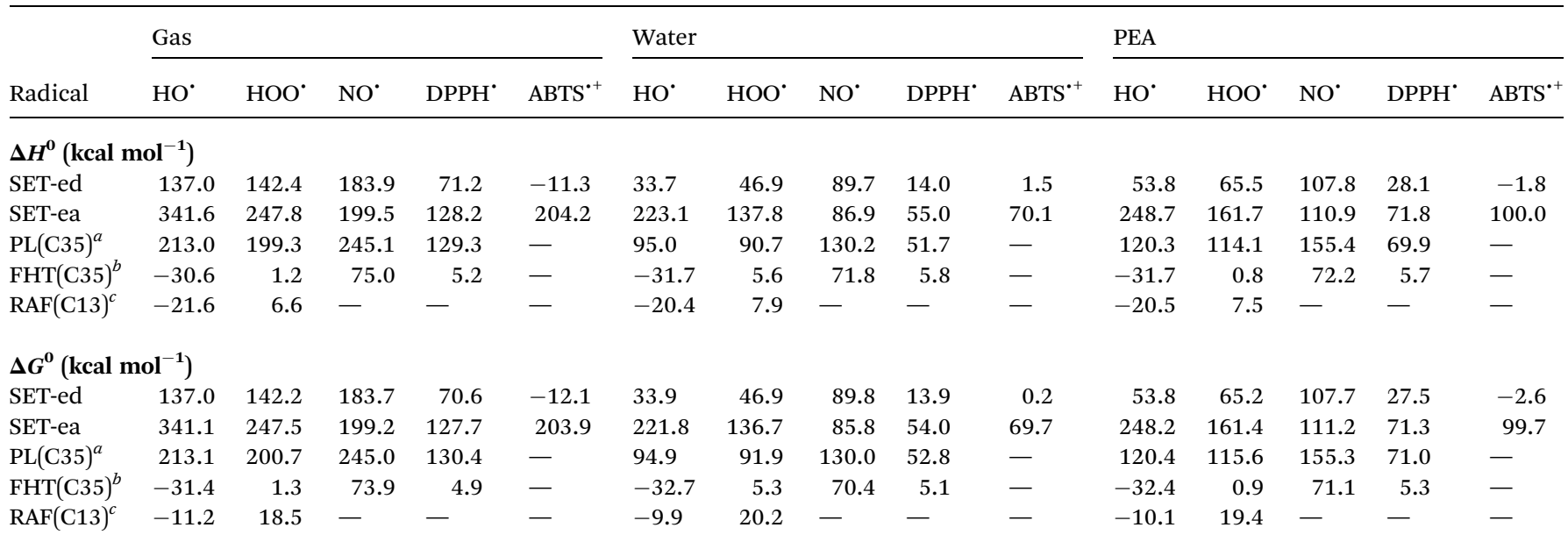

${ }^{a}$ The PL reaction is considered at C35 as: AntioxH $+\mathrm{R}^{\cdot} \rightarrow(\text { Antiox })^{-}+\mathrm{RH}^{{ }^{+}} .{ }^{b}$ The FHT reaction is considered at C35 as: AntioxH $+\mathrm{R}^{\cdot} \rightarrow(\text { Antiox })^{\cdot}+$ RH. ${ }^{c}$ The RAF reaction is considered at $\mathrm{C} 13$ as: Antiox $+\mathrm{R}^{\cdot} \rightarrow\left(\right.$ Antiox-R) ${ }^{\circ}$.

It is clearly observed that for each of the investigated radicals, the electron-donating and electron-accepting capacities are all in the same order as Ir(III) complex $>$ flavonol $>$ ibuprofen, indicating the stronger radical scavenging capacity of the $\operatorname{Ir}($ III) complex compared to the ligands. For example, in the gas phase, the Ir(III) complex quenches $\mathrm{ABTS}^{\cdot+}$ by $-11.3 \mathrm{kcal} \mathrm{mol}^{-1}$, while flavonol and ibuprofen scavenge the same radical by 21.6 and $35.7 \mathrm{kcal} \mathrm{mol}^{-1}$. In water, to scavenge $\mathrm{ABTS}^{\cdot+}, 1.5,18.7$ and $31.2 \mathrm{kcal} \mathrm{mol}^{-1}$ are required for the Ir(III) complex, flavonol and ibuprofen, respectively. In addition, through the SET mechanism, we evaluate the scavenging activity of the Ir(III) complex towards different free radicals both in the gas phase and in solvents (water and PEA). From the results, the antioxidant capacity of the Ir(III) complex towards radicals in water is better than that in PEA and in the gas phase, except for ABTS ${ }^{*+}$. The scavenging capacities of the $\operatorname{Ir}(\mathrm{III})$ complex towards different radicals are in the order $\mathrm{ABTS}^{\circ+}>\mathrm{DPPH}^{*}>\mathrm{HO}^{\circ}>\mathrm{HOO}^{\circ}>\mathrm{NO}^{*}$, with the $\Delta H^{0}$ value for $\mathrm{ABTS}^{{ }^{+}}$and $\mathrm{NO}^{\cdot}$ varying from 1.5 to $89.7 \mathrm{kcal} \mathrm{mol}^{-1}$, from -1.8 to $107.8 \mathrm{kcal} \mathrm{mol}^{-1}$ and from -11.3 to $183.9 \mathrm{kcal} \mathrm{mol}^{-1}$ in water, in PEA and in the gas phase, respectively. This order is somehow shared with the result reported in the experimental part as $\mathrm{DPPH}^{\circ} \approx \mathrm{ABTS}^{\cdot+}>\mathrm{HO}^{\circ}>$ $\mathrm{NO}^{*}$, despite different solvents used in the experiment. For the electron-accepting reaction, all the SET-ea reactions of the $\operatorname{Ir}(\mathrm{III})$ complex with the studied radicals are endergonic and unfavorable in water with both $\Delta H^{0}$ and $\Delta G^{0}$ values being positive (Table 3). The scavenging activity of free radicals by the $\operatorname{Ir}(\mathrm{III})$ complex is in the same order both in the gas phase and in solvents: $\mathrm{DPPH}^{*}>\mathrm{ABTS}^{+} \approx \mathrm{NO}^{\circ}>\mathrm{HOO}^{\circ}>\mathrm{HO}^{\circ}$.

3.5.2. Proton loss reaction. The PL reaction was chosen to calculate for the C35 position due to the lowest PA values found for Ir-C35 in water (Table 2). In all phases, the free radical scavenging was found in the same order as $\mathrm{DPPH}^{*}>$ $\mathrm{HOO}^{\circ}>\mathrm{HO}^{\circ}>\mathrm{NO}^{\circ}$ with $\Delta H^{0}$ values ranging from 129.3 to $245.1 \mathrm{kcal} \mathrm{mol} \mathrm{m}^{-1}$ in the gas phase and from 51.7 to $130.2 \mathrm{kcal} \mathrm{mol}^{-1}$ in water. As a result, the aqueous phase was clearly favored over PEA and the gas phase. Those values, much higher than those of HAT and RAF reactions, indicated that the PL mechanism is anyhow less favored than other mechanisms and is likely not the principal mechanism responsible for the free radical activity of the studied compounds.

3.5.3. Formal hydrogen transfer reaction with $\mathrm{HOO}^{\circ} / \mathrm{HO}^{\circ}$. As seen in Table 3, FHT is the most preponderant scavenging mechanism for all the studied radicals with the lowest reaction enthalpy $\left(\Delta H^{0}\right)$ and Gibbs free energy $\left(\Delta G^{0}\right)$. Indeed, the $\Delta H^{0}$ value of the FHT process towards $\mathrm{HO}^{*}$ radical in water and in PEA is equal to $-31.7 \mathrm{kcal} \mathrm{mol}^{-1}$, whereas the ones of RAF, SET and PL reactions are all higher, being -20.4, 33.7 and $95.0 \mathrm{kcal} \mathrm{mol}^{-1}$, respectively. The same observations can be found in the gas phase and for the other free radicals of interest.

Two typical ROS, the hydroperoxyl radical $\mathrm{HOO}^{\circ}$ and hydroxyl radical $\mathrm{HO}^{\circ}$, for which $\Delta H^{0}$ and $\Delta G^{0}$ were found to be the lowest, were subjects of an in-depth study of the free radical scavenging activity of the Ir(III) complex through the formal $\mathrm{H}$ abstraction. Reactions could be described as (R3) and (R4) for $\mathrm{HOO}^{\circ}$ and $\mathrm{HO}^{\circ}$, respectively:

$$
\begin{gathered}
\mathrm{RH}+\mathrm{HOO}^{\bullet} \rightarrow \mathrm{R}^{\bullet}+\mathrm{HOOH} \\
\mathrm{RH}+\mathrm{HO}^{\bullet} \rightarrow \mathrm{R}^{\bullet}+\mathrm{HOH}
\end{gathered}
$$

Based on the BDE values, one can determine the weakest $\mathrm{C}-\mathrm{H}$ bonds of the $\mathrm{Ir}(\mathrm{III})$ complex at $\mathrm{C} 32$ and $\mathrm{C} 35$ positions; these latter correspond to the most favorable sites for the FHT reaction. The free radical scavenging reactions of $\mathrm{HOO}^{\circ}$ and $\mathrm{HO}^{\circ}$ radicals therefore were studied at these two positions of the Ir(III) complex. Similar reactions were performed with ibuprofen for comparison and results are reported in Table S8 of the ESI. $\dagger$ C35 happened to be the most reactive position for both complex and ligand with lower energies compared to C32 (about $8 \mathrm{kcal} \mathrm{mol}^{-1}$, Table S10 of the ESI $\dagger$ ). 
A similar trend for the scavenging activity of the complex and ligand was observed with a very small difference in term of energy. For example, the $\mathrm{HOO}^{\circ}$ scavenging by the $\mathrm{Ir}(\mathrm{III})$ complex occurring at C35 is endergonic and non-spontaneous with positive Gibbs free energies $\left(\Delta G^{0}\right)$ being $1.3 \mathrm{kcal} \mathrm{mol}^{-1}$ in the gas phase and $5.3 \mathrm{kcal} \mathrm{mol}^{-1}$ in water (Table 3), while the ones of the ligand are $1.2 \mathrm{kcal} \mathrm{mol}^{-1}$ (gas phase) and $5.3 \mathrm{kcal} \mathrm{mol}^{-1}$ (water) (Table S8 $\dagger$ ). Contrarily, the $\mathrm{HO}^{*}$ scavenging through hydrogen transfer mechanism by the Ir(III) complex is exergonic and spontaneous, with negative $\Delta G^{0}$ of $-31.4 \mathrm{kcal} \mathrm{mol}^{-1}$ in the gas phase and $-32.7 \mathrm{kcal} \mathrm{mol}^{-1}$ in water for the same position (Table 3). Values of $\Delta G^{0}$ of the reaction with corresponding positions on ibuprofen ligand were -31.4 and $-32.8 \mathrm{kcal} \mathrm{mol}^{-1}$ in the gas phase and in water, respectively (Table S8 $\dagger$ ).

PEPs of the reaction between the Ir(III) complex and the ligand ibuprofen were also established in order to (i) provide more insight into the chemical kinetics of hydrogen transfer process and (ii) distinguish the nature of FHT reaction: HAT or PCET. For these purposes, geometry optimizations of TSs were firstly performed in the gas phase at the B3LYP/Lanl2dz//6$31 \mathrm{G}(\mathrm{d})$ level of theory. Imaginary frequencies and relative vibrations along the reaction pathway are carefully verified following by intrinsic reaction coordination (IRC) calculation. The imaginary frequencies of all studied reactions are summarized in Table S11 in the ESI. $\dagger$ Reactant intermediates (INT-1) and product intermediates (INT-2) at the lowest energies obtained from IRC for both directions are structurally optimized and enthalpy values are calculated for each molecule, all at the same level of theory.

The obtained results allow one to establish the PEPs of the reaction with $\mathrm{HOO}^{\circ}$ and $\mathrm{HO}^{\circ}$ radicals (Fig. 5). Analysis of optimized structures and frontier orbitals of TSs which are responsible for the hydrogen transfer are presented in Fig. 6.

As has been described previously by many authors for the FHT mechanism, the initial step consists of the approach of the oxygen atom of the $\mathrm{HOO}^{\circ}$ radical to the $\mathrm{H}$ atom of the weak $\mathrm{C}-\mathrm{H}$ bond to form a reactant intermediate complex (INT-1). In the following step, the mitigating $\mathrm{H}$-atom moves away from the carbon atom of Ir(III) complex and tends to form a covalent bond with the oxygen of $\mathrm{HOO}^{\circ}$ radical, consequently forming the TS.
As seen in Fig. 6, at TSs, the $\mathrm{O}-\mathrm{H}$ distances are somewhat shorter than the $\mathrm{C}-\mathrm{H}$ distances $(1.23 \AA$ vs. $1.33 \AA$ for $\mathrm{C} 32$ position and $1.25 \AA$ vs. $1.31 \AA$ for $\mathrm{C} 35$ position). In the next step, another intermediate (INT-2) forms between $\mathrm{H}_{2} \mathrm{O}_{2}$ and the radicalized $\mathrm{Ir}(\mathrm{III})$ complex. Finally, donated $\mathrm{H}$-atom leaves the complex to form $\mathrm{H}_{2} \mathrm{O}_{2}$ and the corresponding radical products. In terms of energy, the reaction barriers $\left(E_{\mathrm{a}}\right)$ rise up to 15.0 and $10.3 \mathrm{kcal} \mathrm{mol}^{-1}$, respectively, while final products were stabilized at 9.7 and $1.2 \mathrm{kcal} \mathrm{mol}^{-1}$ above the reactants for C32 and C35, respectively (Fig. 5A). We observed very similar results for ibuprofen ligand, with $E_{\mathrm{a}}$ found at 15.1 and $13.6 \mathrm{kcal} \mathrm{mol}^{-1}$ while the final products are stabilized at 9.6 and $1.4 \mathrm{kcal} \mathrm{mol}^{-1}$ for C32 and C35, respectively. Shorter O-H distances compared to $\mathrm{C}-\mathrm{H}$ distances at TSs were also found for the reaction of the ligand, i.e. 1.21 vs. $1.34 \AA$ for $\mathrm{C} 32$ position and $1.23 \AA$ vs. $1.32 \AA$ for C35 position (Fig. S11 of the ESI†). C35 is confirmed as the more thermodynamically favored position, consistent with the fact that -C35 is a tertiary C-center radical, which is more stable than a secondary radical such as $-\mathrm{C} 32 .{ }^{54}$ It is also found that the FHT reaction of the Ir(III) complex at the C35 position presents a lower $E_{\mathrm{a}}$ value, i.e. $3.3 \mathrm{kcal} \mathrm{mol}^{-1}$, than the one of ibuprofen ligand. The lower barrier of the Ir(III) complex may explain the higher RSA of the complex as experimentally observed (Fig. 3).

The FHT reaction with $\mathrm{HO}^{\circ}$ radical was studied for the same positions, i.e. $\mathrm{C} 32$ and $\mathrm{C} 35$, on the $\mathrm{Ir}(\mathrm{III})$ complex and also compared with the corresponding positions on ibuprofen ligand. PEP results are shown in Fig. 5B. It is observed that the $\mathrm{HO}^{*}$ scavenging through the FHT mechanism occurs as a barrier-less reaction with $E_{\mathrm{a}}$ lying from -6.0 to $-3.2 \mathrm{kcal} \mathrm{mol}^{-1}$ lower than the reactants. The $\mathrm{H}$-abstraction is exothermic and spontaneous for all positions with final products as the sum of $\operatorname{Ir}(\mathrm{III})$ complex radical and $\mathrm{H}_{2} \mathrm{O}$ of -30.6 to $-22.1 \mathrm{kcal} \mathrm{mol}^{-1}$ lower than the reactants. At C32 position, the scavenging process by the Ir(III) complex and by ibuprofen takes place almost in the same manner in terms of energy. For example, the reactant intermediates (INT-1) were found at $-1.5 \mathrm{kcal} \mathrm{mol}^{-1}$ for the Ir(III) complex and $-2.0 \mathrm{kcal} \mathrm{mol}^{-1}$ for ibuprofen while the TSs at -3.2 and $-3.6 \mathrm{kcal} \mathrm{mol}^{-1}$ and the products at -22.1 and $-22.2 \mathrm{kcal} \mathrm{mol}^{-1}$ were determined for complex and ligand, respectively. At C35 position, bigger gaps of
A

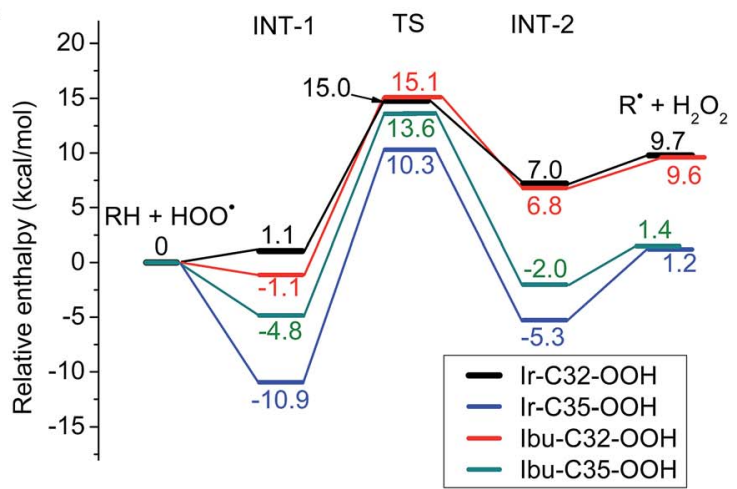

B

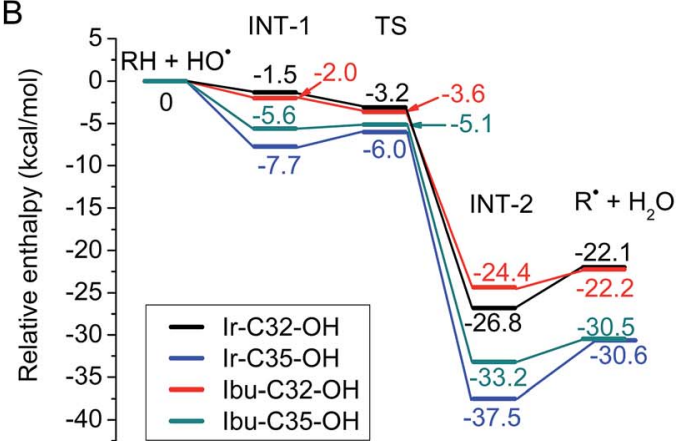

Fig. 5 Potential energy profiles of FHT reaction of $\operatorname{Ir}(\mathrm{II})$ complex and ibuprofen with $\mathrm{HOO}^{*}(\mathrm{~A})$ and $\mathrm{HO} \mathrm{O}^{*}(\mathrm{~B})$ radicals calculated in the gas phase at the B3LYP/Lanl2dz/6-31G(d) level of theory for C32 and C35 positions. 

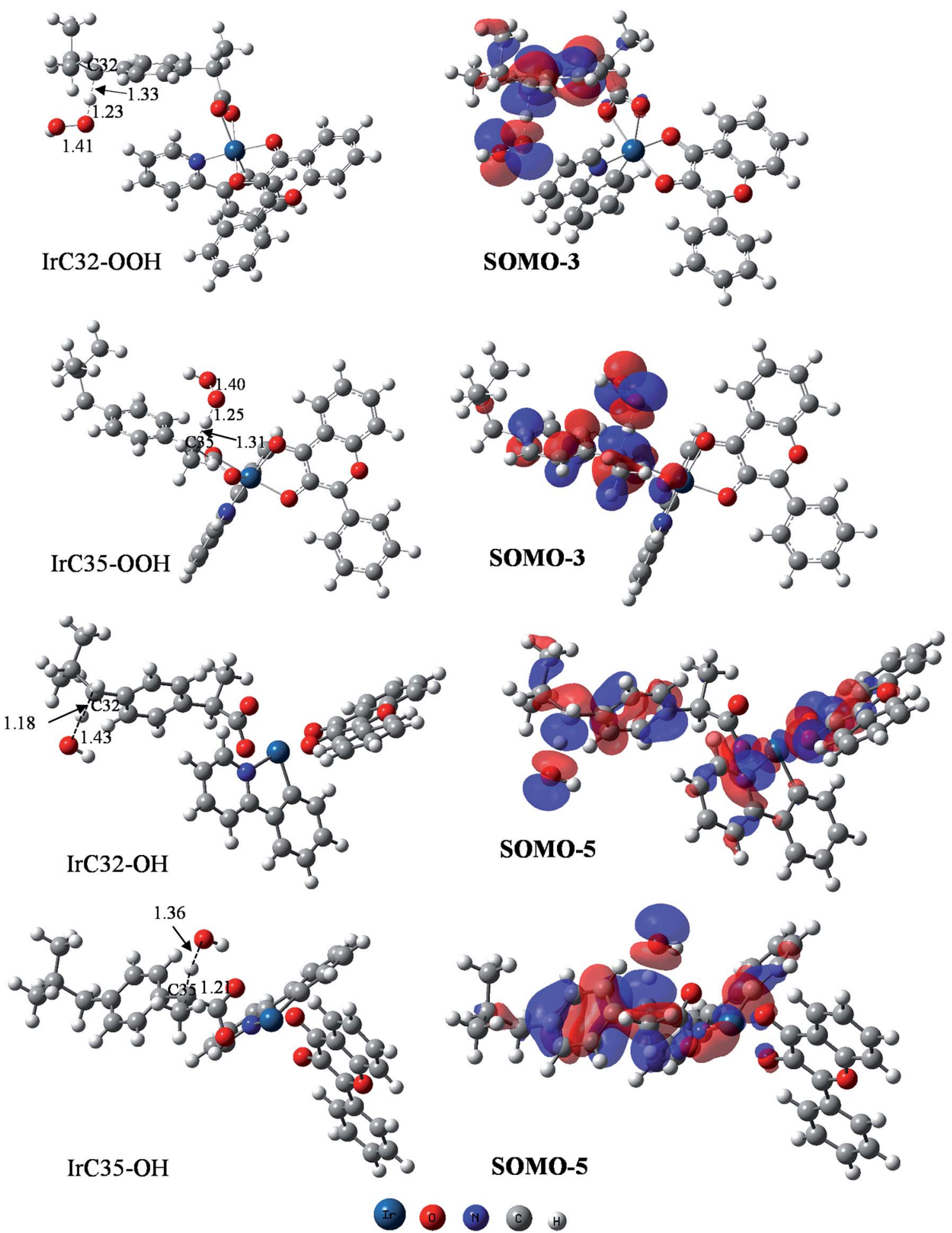

Fig. 6 Optimized transition structures (left) and frontier orbitals (right) responsible for the HAT reaction between $\mathrm{HOO} / \mathrm{HO}^{\circ}$ and Ir(III) complex occurring at $\mathrm{C} 32-\mathrm{H}$ and $\mathrm{C} 35-\mathrm{H}$ positions (isovalue $=0.02$ for the contour).

energy between the Ir(III) complex and ibuprofen were observed. Indeed, the reactant intermediates (INT-1) were found at -7.7 and $-5.6 \mathrm{kcal} \mathrm{mol}^{-1}$, the TSs at -6.0 and $-5.1 \mathrm{kcal} \mathrm{mol}^{-1}$, and the product intermediate (INT-2) at -37.5 and $-33.2 \mathrm{kcal} \mathrm{mol}^{-1}$ for Ir(III) complex and ibuprofen, respectively. The C35 position on the $\operatorname{Ir}(\mathrm{III})$ complex is also the most thermodynamically favored position for the $\mathrm{FHT}$ reaction with $\mathrm{HO}^{\circ}$, which is in agreement with the $\mathrm{HOO}^{\circ}$ scavenging result.

Regarding the $\mathrm{H}$-abstraction steps, hydrogen bonding intermediates formed between the oxygen atom of $\mathrm{HO}^{\circ}$ radical and the $\mathrm{H}$-mitigating atom, similarly as for the $\mathrm{HOO}^{\circ} \mathrm{scav}^{-}$ enging. At TSs, elongated $\mathrm{C}-\mathrm{H}$ bonds were observed, while the 
H-O distances are shortened, e.g. $1.18 \AA$ A vs. $1.43 \AA$ for $\mathrm{C}-\mathrm{H} v s$. $\mathrm{O}-\mathrm{H}$ of $\mathrm{C} 32$ and $1.21 \AA$ vs. $1.36 \AA$ for $\mathrm{C}-\mathrm{H} v s$. O-H of $\mathrm{C} 35$ position (Fig. 6). Similar results were obtained for corresponding positions on ibuprofen ligand (Fig. S8 of the ESI $\dagger$ ). Finally, the $E_{\mathrm{a}}$ value of the reaction between the $\mathrm{Ir}(\mathrm{III})$ complex and $\mathrm{HO}^{\circ}$ radical at the C35 position is also lower than that of ibuprofen ligand,

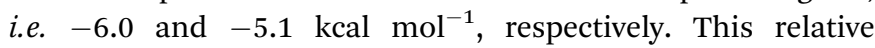
tendency is identical to the results for HOO ${ }^{*}$ radical scavenging and probably corresponds to higher activity of complex compared to ligands as observed in the experimental part.

Concerning the $\mathrm{H}$ mitigation, it is essential to understand the precise mechanism as HAT or PCET. Although reactants and products of the two mechanisms are identical, the electron and the proton are transferred differently in two distinct ways. In the HAT process, the electron and the proton are transferred together as a single entity $\left(\mathrm{H}^{\circ}\right)$ in a single step, while in the PCET process, the proton $\left(\mathrm{H}^{+}\right)$and the electron $\left(\mathrm{e}^{-}\right)$are separately transferred as two subatomic entities. In order to distinguish the HAT/PCET mechanism, the frontier orbitals as well as the NBO of TSs are carefully analyzed. NPA charges, Hirshfeld ASD, NAO occupancy and NEC analyses provide more information for the $\mathrm{H}$ transfer mechanism.

Indeed, when analyzing the frontier orbitals of TSs, the SOMOs, as expected, are found to be located along the $\mathrm{H}$ transfer pathway (donor-H-acceptor) in the case of ibuprofen ligand, for both C32 and C35 positions (Fig. S11 of ESI $\dagger$ ). However, for the $\operatorname{Ir}(\mathrm{III})$ complex, all SOMOs are found to be always on 2-phenylpyridine moiety, similarly to the HOMO of the original complex, but not on ibuprofen and certainly not at the reactive positions. This unexpected result drives us to examine other frontier orbitals of the complex to search for the $\mathrm{H}$-transfer-responsible orbital. Consequently, for $\mathrm{HOO}^{*}$ scavenging, the SOMO-3 orbitals are found to be located on the ibuprofen moiety as well as the $\mathrm{H}$-transition vector while the SOMO-5 orbitals are responsible in the case of $\mathrm{HO}^{\circ}$ scavenging (Fig. 6). As can be seen on the SOMO-3 orbitals, 2p orbitals of $\mathrm{H}$ donor ( $\mathrm{C}$ atom on the complex) and $\mathrm{H}$-acceptor ( $\mathrm{O}$ atom of $\mathrm{HOO}^{\circ} / \mathrm{HO}^{\circ}$ radical) are similarly distributed along the $\mathrm{H}$ transferring vector with a node plan located at the transferred $\mathrm{H}$ atom. This observation corresponds to $\mathrm{H}$-atom transfer process from the ibuprofen moiety to $\mathrm{HOO}^{*} / \mathrm{HO}^{*}$ free radical via an interaction of the SOMO-3 or SOMO-5 orbitals. ${ }^{55,56}$

NBO analysis (Table 4) shows that at TSs of the HAT reaction with $\mathrm{HOO}^{\circ}$, the electron densities are transferred from the third lone pair of the reactive oxygen on $\mathrm{HOO}^{\circ}, \mathrm{LP}(3) \mathrm{O} 81$, to the first unoccupied anti-bonding orbitals of the donated $\mathrm{H}$ atom, i.e. LP*(1) H45 and LP*(1) H47, with stabilization energies corresponding to 87.1 and $119.7 \mathrm{kcal} \mathrm{mol}^{-1}$. Another interaction was found between the $\sigma$-bonding orbitals of the newly formed bond H45-O81, $\sigma(1) \mathrm{H} 45-\mathrm{O} 81$, and the first unoccupied antibonding orbitals of C32, LP*(1) C32, with stabilization energy of $53.6 \mathrm{kcal} \mathrm{mol}^{-1}$. The unoccupied anti-bonding orbital of the newly formed bond H45-O81, $\sigma^{*}(1) \mathrm{H} 45-\mathrm{O} 81$, also interacts with the first lone pair anti-bonding orbital of C32, LP*(1) C32, with stabilization energy of $47.9 \mathrm{kcal} \mathrm{mol}^{-1}$. In the case of $\mathrm{C} 35$, the third lone pair of $\mathrm{O} 81, \mathrm{LP}(3) \mathrm{O} 81$, is transferred to the first unoccupied anti-bonding orbital of the C35-H47 bond, $\sigma^{*}(1)$ C35-H47, with a stabilization energy equal to $63.2 \mathrm{kcal} \mathrm{mol}^{-1}$ while the second lone pair of $\mathrm{O} 81, \mathrm{LP}(2) \mathrm{O} 81$, is transferred to the first lone pair unoccupied of $\mathrm{H}$ atom, LP*(1) H47, with a stabilization energy of $26.2 \mathrm{kcal} \mathrm{mol}^{-1}$. The orbital interactions are in agreement with previous reports on the HAT reaction of $\mathrm{HOO}^{\cdot 56}$

Table 4 NBO analysis of TSs of HAT reactions between Ir(III) complex and $\mathrm{HOO} / \mathrm{HO}^{\circ}$ at C32 and C35 positions and RAF reactions at C12 and C13 positions

\begin{tabular}{|c|c|c|c|c|}
\hline Reaction & Bond & Donor NBO $(i)$ & Acceptor NBO $(j)$ & $E_{2}\left(E_{i}-E_{j}\right)\left(\mathrm{kcal} \mathrm{mol}^{-1}\right)$ \\
\hline \multirow[t]{5}{*}{ HAT-HOO ${ }^{\circ}$} & $\mathrm{C} 32 \cdots \mathrm{H} 45 \cdots \mathrm{O} 81$ & LP(3) O81 & $\mathrm{LP}^{*}(1) \mathrm{H} 45$ & 87.1 \\
\hline & & $\mathrm{LP}^{*}(1) \mathrm{C} 32$ & $\sigma^{*}(1) \mathrm{H} 45-\mathrm{O} 81$ & 47.9 \\
\hline & $\mathrm{C} 35 \cdots \mathrm{H} 47 \cdots \mathrm{O} 81$ & $\mathrm{LP}(3) \mathrm{O} 81$ & $\mathrm{LP}^{*}(1) \mathrm{H} 47$ & 119.7 \\
\hline & & $\mathrm{LP}(2) \mathrm{O} 81$ & $\mathrm{LP}^{*}(1) \mathrm{H} 47$ & 26.2 \\
\hline & & $\mathrm{LP}(3) \mathrm{O} 81$ & $\sigma^{*}(1) \mathrm{C} 35-\mathrm{H} 47$ & 63.2 \\
\hline & & $\mathrm{LP}^{*}(3) \mathrm{O} 1$ & $\mathrm{LP}^{*}(1) \mathrm{H} 45$ & 66.5 \\
\hline & $\mathrm{C} 35 \cdots \mathrm{H} 47 \cdots \mathrm{O} 81$ & LP(3) O81 & $\sigma^{*}(1) \mathrm{C} 35-\mathrm{H} 47$ & 40.8 \\
\hline & & $\mathrm{LP}(2) \mathrm{O} 81$ & $\mathrm{LP}^{*}(1) \mathrm{H} 47$ & 18.4 \\
\hline & & $\mathrm{LP}^{*}(3) \mathrm{O} 1$ & $\mathrm{LP}^{*}(1) \mathrm{H} 47$ & 80.3 \\
\hline \multirow[t]{2}{*}{ RAF-HOO } & $\mathrm{C} 12 \cdots \mathrm{O} 83$ & LP(3) 083 & $\mathrm{LP}^{*}(1) \mathrm{C} 12$ & 64.5 \\
\hline & & LP(1) O83 & $L P^{*}(1) \mathrm{C} 12$ & 6.8 \\
\hline \multirow[t]{4}{*}{ RAF-HO' } & $\mathrm{C} 12 \cdots \mathrm{O} 81$ & $\mathrm{LP}^{*}(3) \mathrm{O} 81$ & $\mathrm{LP}(1) \mathrm{C} 12$ & 319.4 \\
\hline & $\mathrm{C} 13 \cdots \mathrm{O} 81$ & $\sigma(2) \mathrm{C} 13-\mathrm{C} 17$ & $\mathrm{LP}^{*}(4) \mathrm{O} 81$ & 29.6 \\
\hline & & $\mathrm{LP}(1) \mathrm{O} 81$ & $\mathrm{LP}^{*}(1) \mathrm{H} 82$ & 15.0 \\
\hline & & LP(3) O81 & $\mathrm{LP}^{*}(1) \mathrm{H} 82$ & 362.4 \\
\hline
\end{tabular}


Table 5 Natural population analysis (NPA) charge, atomic spin densities (ASD), $1 \mathrm{~s}$ occupancy and natural electronic configuration (NEC) of the mitigating $\mathrm{H}$ and involved $\mathrm{C}$ and $\mathrm{O}$ atoms at the transition states of the HAT reaction

\begin{tabular}{|c|c|c|c|c|c|c|}
\hline \multirow[t]{9}{*}{$\mathrm{HOO}^{\circ}$} & \multirow[t]{2}{*}{ Ir-C32 } & $\mathrm{H}$ & 0.38441 & 0.026972 & \multirow[t]{2}{*}{0.61255} & \multirow[t]{2}{*}{$1 \mathrm{~s}^{0.6}$} \\
\hline & & $\mathrm{C}$ & -0.36909 & 0.279536 & & \\
\hline & \multirow[t]{3}{*}{ Ir-C35 } & $\mathrm{H}$ & 0.39686 & 0.020084 & \multirow[t]{3}{*}{0.59962} & \multirow[t]{3}{*}{$1 \mathrm{~s}^{0.60}$} \\
\hline & & $\mathrm{C}$ & -0.27871 & 0.256208 & & \\
\hline & & $\mathrm{O}$ & -0.32228 & 0.381153 & & \\
\hline & Ibu-C32 & $\mathrm{O}$ & -0.35308 & 0.351018 & 0.60584 & $1 \mathrm{~s}^{0.61}$ \\
\hline & \multirow[t]{3}{*}{ Ibu-C35 } & $\mathrm{H}$ & 0.39688 & 0.017137 & \multirow[t]{3}{*}{0.59982} & \multirow[t]{3}{*}{$1 \mathrm{~s}^{0.60}$} \\
\hline & & $\mathrm{C}$ & -0.28856 & 0.257628 & & \\
\hline & & $\mathrm{O}$ & -0.33374 & 0.372410 & & \\
\hline \multirow[t]{8}{*}{$\mathrm{HO}^{\circ}$} & \multirow[t]{2}{*}{ Ir-C32 } & $\mathrm{H}$ & 0.30869 & 0.029091 & \multirow[t]{2}{*}{0.68880} & \multirow[t]{2}{*}{$1 s^{0.69}$} \\
\hline & & $\mathrm{C}$ & -0.24770 & 0.208034 & & \\
\hline & \multirow[t]{3}{*}{ Ibu-C32 } & $\mathrm{H}$ & 0.31026 & 0.029696 & \multirow[t]{3}{*}{0.68733} & \multirow[t]{3}{*}{$1 s^{0.69}$} \\
\hline & & $\mathrm{C}$ & -0.39111 & 0.205974 & & \\
\hline & & $\mathrm{O}$ & -0.64913 & 0.626864 & & \\
\hline & \multirow[t]{3}{*}{ Ibu-C35 } & $\mathrm{H}$ & 0.33735 & 0.027386 & \multirow[t]{3}{*}{0.65967} & \multirow[t]{3}{*}{$1 \mathrm{~s}^{0.66}$} \\
\hline & & $\mathrm{C}$ & -0.27383 & 0.235012 & & \\
\hline & & $\mathrm{O}$ & -0.65995 & 0.607433 & & \\
\hline
\end{tabular}

For the HAT reaction with $\mathrm{HO}^{\circ}$, very similar donor-acceptor orbital couples were observed for the C32 and C35 positions. For example, the third lone pair of the reactive oxygen atom, $\mathrm{LP}(3) \mathrm{O} 81$, is transferred to the $\sigma$ anti-bonding orbital of the $\mathrm{C}-\mathrm{H}$ bond, $\sigma^{*}(1) \mathrm{C} 32-\mathrm{H} 45$ or $\sigma^{*}(1) \mathrm{C} 35-\mathrm{H} 47$, with 31.5 or 40.8 kcal mol; the second lone pair of the reactive oxygen atom, $\operatorname{LP}(2)$ O81, is transferred to the first lone pair unoccupied antibonding orbital of mitigating hydrogen atom, LP*(1) H45 or $\mathrm{LP}^{*}(1) \mathrm{H} 47$, with 14.1 or $18.4 \mathrm{kcal} \mathrm{mol}$; the third unoccupied lone pair of reactive oxygen atom, LP*(3) O81, transfers to the first unoccupied lone pair of mitigating hydrogen atom, LP*(1) $\mathrm{H} 45$ or LP*(1) H47, with 66.5 or $80.3 \mathrm{kcal} \mathrm{mol}^{-1}$.
As can be seen in Table 5, the NPA charges of the mitigating $\mathrm{H}$ are found as positive at about $0.31-0.4 \mathrm{e}^{-}$, similar to that reported in the literature for the HAT mechanism $\left(0.3 \mathrm{e}^{-}\right) \cdot{ }^{57}$ Very small Hirshfeld ASDs varying from 0.0171 to 0.0297 were found for the mitigating $\mathrm{H}$, while significantly higher values were obtained on the donor and acceptor atoms (0.176-0.306 for $\mathrm{C}$ atoms and 0.351-0.636 for $\mathrm{O}$ atoms). The NPA charges and Hirshfeld ASD values of carbon and oxygen atoms involved in the reaction are also presented in Table 5 for comparison. In addition, the NEC also shows that the mitigating $\mathrm{H}$ is characterized by $1 \mathrm{~s}^{0.60-0.69}$ orbital configurations which seem similar to $1 \mathrm{~s}^{1}$ orbital. The mitigating $\mathrm{H}$ atom therefore has a hydrogen-
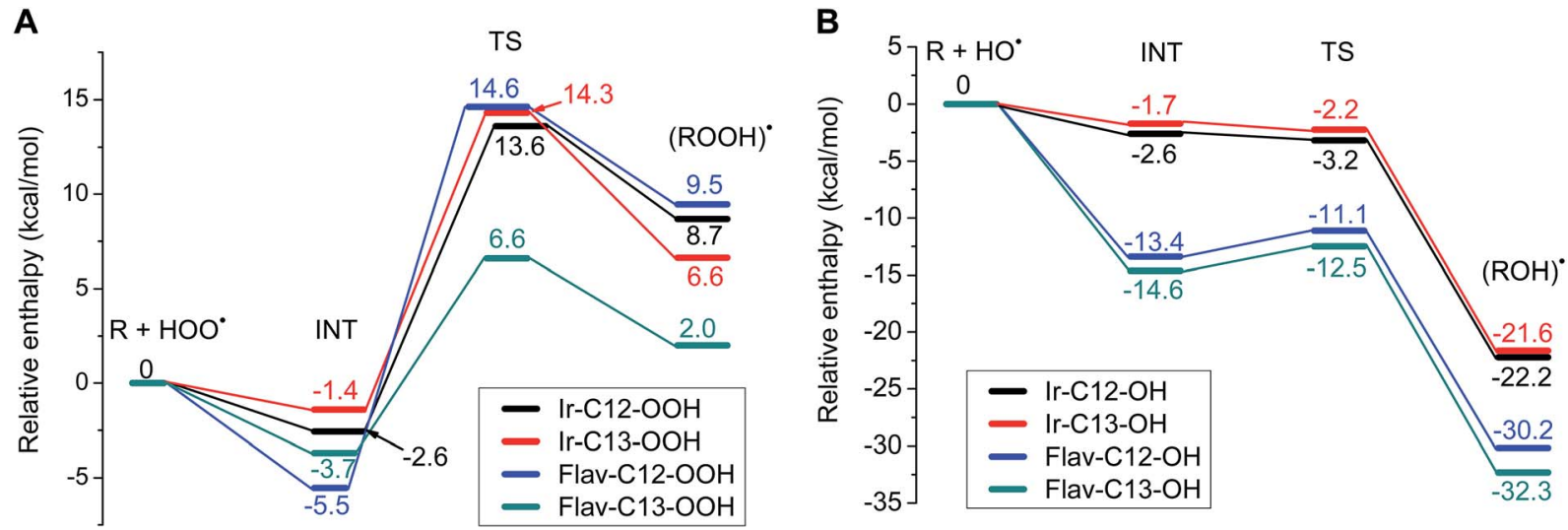

Fig. 7 Potential energy profiles of RAF reaction between $\operatorname{Ir}(\mathrm{II})$ complex and $\mathrm{HOO}^{*}(\mathrm{~A})$ and $\mathrm{OH}^{*}(\mathrm{~B})$ radicals calculated in the gas phase at $\mathrm{B} 3 \mathrm{LYP} /$ Lanl2dz//6-31G(d) level of theory for C12 and C13 positions and for the corresponding positions on flavonol ligand. 
atom-like character rather than being a proton-like species. Overall, the NBO analysis is in agreement with the frontier orbital analysis and strongly supports the H-transfer mechanism as HAT process.

3.5.4. Radical adduct formation reaction with $\mathrm{HOO}^{\circ} / \mathrm{HO}^{\circ}$. Since the ligands of the Ir(III) complex include unsaturated bonds, the $\mathrm{HOO}^{*} / \mathrm{HO}^{*}$ scavenging activity might occur through the RAF mechanism. Reactions could be described as follows:

$$
\begin{gathered}
\mathrm{R}+\mathrm{HOO}^{\circ} \rightarrow(\mathrm{ROOH})^{\circ} \\
\mathrm{R}+\mathrm{HO}^{\circ} \rightarrow(\mathrm{ROH})^{\circ}
\end{gathered}
$$

Results from semi-empirical calculations show that four positions, i.e. $\mathrm{C} 12$ and $\mathrm{C} 13$ on flavonol ligand and $\mathrm{C} 38$ and $\mathrm{C} 40$ on ibuprofen ligand, seem to be the most probable sites for the RAF reaction with HOO (Table S12 of the ESI $\dagger$ ). Based on the reaction enthalpy and Gibbs free energy calculated at higher level of DFT calculation for all positions of the Ir(III) complex with HOO' (Table S13 of the ESI $\dagger$ ), we selected to illustrate the RAF reaction on $\mathrm{C} 12$ and $\mathrm{C} 13$ (Table S14 of ESI $\dagger$ ). The RAF reaction with $\mathrm{HO}^{\circ}$ radicals was also performed on the same positions for Ir(III) complex and flavonol ligand.

As can be seen in Table 3, the RAF seems to be the secondmost-favored scavenging mechanism for all studied radicals with very low reaction enthalpy $\left(\Delta H^{0}\right)$ and Gibbs free energy
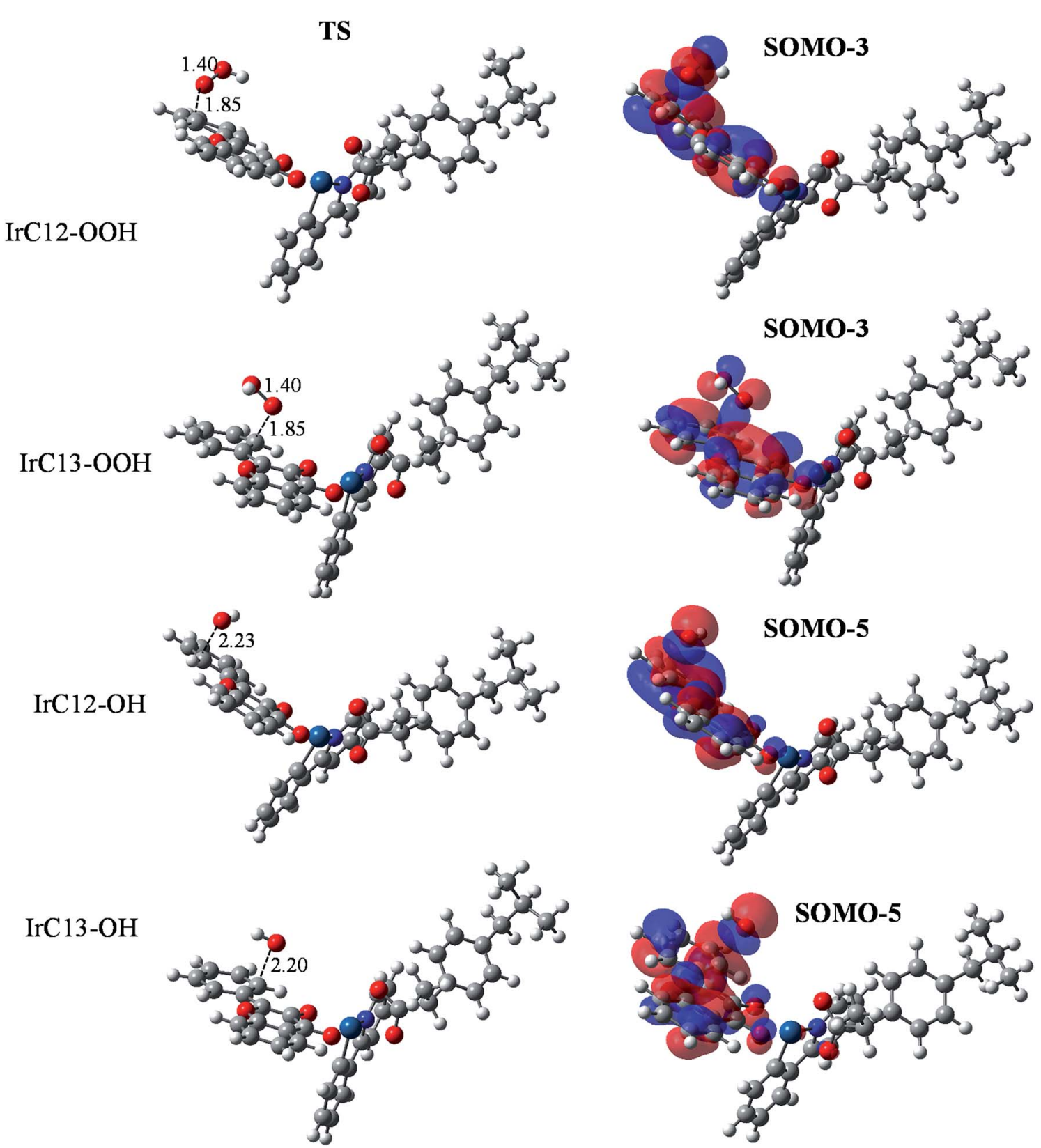

Fig. 8 Optimized transition structures (TS) and frontier orbitals of the RAF reaction between $\mathrm{HOO} / \mathrm{HO}^{\circ}$ and $\operatorname{lr}(\mathrm{II})$ complex, occurring at $\mathrm{C} 12$ and C13 positions (isovalue $=0.02$ ) 
$\left(\Delta G^{0}\right)$. The $\Delta H^{0}$ value of the RAF towards HO radical in water is equal to $-21.6 \mathrm{kcal} \mathrm{mol}^{-1}$, only about $10 \mathrm{kcal} \mathrm{mol}^{-1}$ higher than $\Delta H^{0}$ of the HAT reaction but much lower than $\Delta H^{0}$ of SET $\left(137.0 \mathrm{kcal} \mathrm{mol}^{-1}\right)$ and PL $\left(213.0 \mathrm{kcal} \mathrm{mol}^{-1}\right)$ reactions. The same observations can be found for the $\mathrm{HOO}^{\star}$ radical. In addition, almost identical enthalpies were found for the same radical both in the gas phase and in solvent, e.g. for $\mathrm{HO}^{*}$ we found an enthalpy of -21.6 in the gas phase, -20.4 in water and $-20.5 \mathrm{kcal} \mathrm{mol}^{-1}$ in PEA. The addition process for HOO ${ }^{*}$ is endothermic and non-spontaneous while the same process for $\mathrm{HO}^{*}$ is exothermic and spontaneous for both $\operatorname{Ir}(\mathrm{III})$ complex and flavonol; the trend is very similar to that for the HAT mechanism. We can however observe that the reaction seems to be favored at C13 rather than C12 with lower enthalpy and Gibbs free energy (of about $2-10 \mathrm{kcal} \mathrm{mol}^{-1}$, Table S14 of the ESI $†$ ). In particular, the flavonol ligand seems to be better than the $\operatorname{Ir}($ III) complex in scavenging $\mathrm{HOO}^{\circ}$ and $\mathrm{HO}^{\circ}$ radicals with the Gibbs free energy almost equal to or lower than that of the $\operatorname{Ir}(\mathrm{III})$ complex, e.g. 14.3 vs. 18.5 for $\mathrm{HOO}^{\circ}$ and -21.4 vs. -11.2 for $\mathrm{HO}^{\circ}$ radicals at the $\mathrm{C} 13$ position (Table S14 of the ESI $\dagger$ ).

The PEPs of the RAF reaction with $\mathrm{HOO}^{\circ}$ and with $\mathrm{HO}^{\circ}$ radicals are displayed in Fig. 7. As can be seen in Fig. 7, the $\mathrm{HOO}^{\circ}$ radical adduct formation is an endothermic and nonspontaneous process. The reactant intermediate complexes (INT) formed with an energy lying several kcal mol${ }^{-1}$ below the separated reactants, e.g. $-1.4 \mathrm{kcal} \mathrm{mol}^{-1}$ to $-5.5 \mathrm{kcal} \mathrm{mol}^{-1}$ in the case of Ir-C13 to Flav-C12. Reaction barriers $\left(E_{\mathrm{a}}\right)$ of about $14 \mathrm{kcal} \mathrm{mol}^{-1}$ were observed in most cases, except for Flav-C13, which is characterized by a much lower TS energy (6.6 kcal $\left.\mathrm{mol}^{-1}\right)$. The radical products obtained by forming a chemical bond between the reactive $\mathrm{O}$ and $\mathrm{C}$ sites have stabilized energies of 9.5, 8.7, 6.6 and $2.0 \mathrm{kcal} \mathrm{mol}^{-1}$ for FlavC12, Ir-C12, Ir-C13 and Flav-C13, respectively. The C13 position is more favored than $\mathrm{C} 12$ in the $\mathrm{HOO}^{*}$ adduct formation for both $\operatorname{Ir}(\mathrm{III})$ complex and flavonol ligand.

Regarding the $\mathrm{HO}^{\circ}$ adduct formation at the same $\mathrm{C} 12$ and C13 positions on the Ir(III) complex and the corresponding positions on flavonol, the reaction is exothermic and exergonic in all cases. We observed a similar behavior for Flav-C12 and Flav-C13, while almost identical energies were observed for Ir$\mathrm{C} 12$ and Ir-C13. The reaction is barrier-less with energies of all TS $\left(E_{\mathrm{a}}\right)$ complexes lying at $-2.2,-3.2,-11.1$ and $-12.5 \mathrm{kcal} \mathrm{mol}^{-1}$ for Ir-C13, Ir-C12, Flav-C12 and Flav-C13, respectively. Final radical products were stabilized at -21.6 , $-22.2,-30.2$ and $-32.3 \mathrm{kcal} \mathrm{mol}^{-1}$ below the reactants for IrC13, Ir-C12, Flav-C12 and Flav-C13, respectively. Again in HO' scavenging through the RAF mechanism, the C13 position is more favored than the $\mathrm{C} 12$ position, for both Ir(III) complex and ligand. It is seen that for the RAF mechanism, the flavonol ligand shows better RSA than the Ir(III) complex, towards both $\mathrm{HO}^{\circ}$ and $\mathrm{HOO}^{\circ}$, which is not surprising considering the very good antioxidant properties known for flavonol.

Optimized structures and frontier orbital analysis of TSs of the $\operatorname{Ir}(\mathrm{III})$ complex are presented in Fig. 8. At TSs, the reactive oxygen atoms is $1.85 \AA$ distant from the reactive carbon atom in the case of $\mathrm{HOO}^{\circ}$ radical, while this distance is about 2.20-2.23 $\AA$ in the case of $\mathrm{HO}^{\circ}$ radical. Similar to the HAT reaction, frontier orbital analysis revealed that SOMO-3 orbitals are responsible for the $\mathrm{HOO}^{*}$ scavenging while the SOMO-5 orbitals are responsible in case of $\mathrm{HO}^{\circ}$ scavenging, in which we can clearly observe an overlap between the $2 \mathrm{p}$ orbitals on $\mathrm{O}$ atoms with the $\pi$ orbitals of the $\mathrm{C}=\mathrm{C}$ double bonds (Fig. 8). NBO analysis (Table 4) revealed that for the $\mathrm{HOO}^{*}$ scavenging reaction by the Ir(III) complex, the third lone pair of the reactive oxygen atom (O83), LP(3) O83, donates electrons to the unoccupied anti-bonding orbital of the reactive carbon atoms (C12 or C13), LP*(1) C12 or LP*(1) C13, with stabilization energies of 64.5 or $63.6 \mathrm{kcal} \mathrm{mol}^{-1}$. Meanwhile, the interaction between the first lone pair of the reactive oxygen atom (O83), LP(1) O83, and the unoccupied anti-bonding orbital of the reactive carbon atoms (C12 or C13), LP*(1) C12 or LP*(1) C13, is determined as only 6.8 or $6.9 \mathrm{kcal} \mathrm{mol}^{-1}$. This result is in good agreement with the SOMO analysis which demonstrated that SOMO-3 are the responsible orbitals for the RAF reaction with $\mathrm{HOO}^{-}$radical. Results obtained for $\mathrm{HO}^{\circ}$ scavenging through the RAF mechanism show that the reaction at the $\mathrm{C} 12$ position involved the third unoccupied lone pair of the oxygen atom, LP* (3) O81, and the first lone pair of the carbon atom, $\operatorname{LP}(1) \mathrm{C} 12$, with stabilization energy of $319.4 \mathrm{kcal} \mathrm{mol}^{-1}$. For the $\mathrm{C} 13$ position, the $\sigma$ bonding orbitals of the C13-C17 bonds, $\sigma(2) \mathrm{C} 13-\mathrm{C} 17$, transfer to the fourth lone pair anti-bonding orbital of O81, LP*(4) O81, with stabilization energy of $29.6 \mathrm{kcal} \mathrm{mol}^{-1}$.

\section{Concluding remarks}

In summary, we have reported the synthesis and characterization of an $\operatorname{Ir}(\mathrm{III})$ complex based on biologically important ligands, ibuprofen and flavonol. The complex demonstrated better free radical scavenging activity than the ligands for most common radicals $\left(\mathrm{ABTS}^{+}, \mathrm{DPPH}^{\circ}, \mathrm{NO}^{\circ}, \mathrm{HO}^{\circ}\right)$. The complex preliminarily shows good in vitro antitumor activity towards A549, A2780 and A2780cis cells and its cytotoxicity is significantly greater than that of cis-platin and the ligands in the same conditions.

In parallel, theoretical investigation by DFT was employed to study the geometrical and electronic structures of the complex as well as of the ligands. Intrinsic thermochemical properties of all compounds calculated in both the gas phase and in two solvents (water and PEA) revealed also that the Ir(III) complex is a potent antioxidant and its antioxidant capacity is greater than that of the ligands, in agreement with the experimental investigation. Principal reactions of free radical scavenging of the Ir(III) complex were chosen to study in detail, including the HAT, the RAF and the SET mechanisms. Findings are summarized as follows:

- for the SET reaction, electron-donating process is preferred over electron-accepting one both in the gas phase and in solvents, for all studied radicals.

- The PL mechanism is among the less favored pathways for free radical scavenging. Nevertheless, it is noted that the radicals could be scavenged in the order $\mathrm{DPPH}^{\circ}>\mathrm{HOO}^{\circ}>\mathrm{HO}^{*}>\mathrm{NO}^{*}$ in both phases.

- The FHT mechanism was proved to be the most active pathway for free radical scavenging towards $\mathrm{HO}^{\circ}, \mathrm{HOO}^{\circ}, \mathrm{NO}^{\circ}$ 
and $\mathrm{DPPH}^{\circ}$. The FHT reaction towards $\mathrm{HOO}^{\circ}$ radical is endothermic and non-spontaneous while the same reaction towards $\mathrm{HO}^{*}$ radical is exothermic and spontaneous. C35 is the most favorable position for the FHT mechanism in both cases. The $\mathrm{H}$ abstraction was confirmed to be directed by the HAT mechanism but not PCET by analyzing the frontier orbitals and from NBO analyses of TSs. In our computational conditions (gas phase), the Ir(III) complex shows similar enthalpy of reactions but lower barrier for the same position as ibuprofen, which might be an indication for the higher radical scavenging activity of the complex compared to ligands.

- Similar results were obtained for the RAF reaction with $\mathrm{HOO}^{*} / \mathrm{HO}^{*}$ radicals. The radical adduct of HOO${ }^{*}$ is endothermic and non-spontaneous while the RAF reaction towards $\mathrm{HO}^{\circ}$ radical is exothermic and spontaneous. C13 and C12 are the most favored positions for $\mathrm{HOO}^{\circ}$ and $\mathrm{HO}^{\circ}$, respectively. Flavonol, in our computational condition (gas phase), shows better antioxidant property via RAF mechanism than the $\operatorname{Ir}(\mathrm{III})$ complex.

The study also demonstrated that theoretical and experimental investigation could be used effectively as complementary to evaluate structures and properties, especially antioxidant properties of molecules. Finally, we hope that the present work will mark a further step in the design and synthesis of new anticancer metallodrugs based on bioactive ligands.

\section{Conflicts of interest}

The authors declare no competing financial interest.

\section{Abbreviations}

$\begin{array}{ll}\text { ROS } & \text { Reactive oxygen species } \\ \text { ABTS } & \text { 2,2'-Azinobis(3-ethylbenzthiazoline-6-sulphonic acid) } \\ \text { DPPH } & \text { 2,2-Diphenyl-1-picrylhydrazyl } \\ \text { HOMO } & \text { Highest occupied molecular orbital } \\ \text { LUMO } & \text { Lowest unoccupied molecular orbital } \\ \text { SOMO } & \text { Singly occupied molecular orbital } \\ \text { FHT } & \text { Formal hydrogen transfer } \\ \text { RAF } & \text { Radical adduct formation } \\ \text { BDE } & \text { Bond dissociation enthalpy } \\ \text { IP } & \text { Ionization potential } \\ \text { EA } & \text { Electron affinity } \\ \Delta H^{0} & \text { Adiabatic reaction enthalpy } \\ \Delta G^{0} & \text { Gibbs free energy } \\ \text { NBO } & \text { Natural bond orbital } \\ \text { SET } & \text { Single electron transfer } \\ \text { PL } & \text { Proton loss } \\ \text { PA } & \text { Proton affinity } \\ \text { ZPE } & \text { Zero-point vibrational energy } \\ \text { ESR } & \text { Electron spin resonance }\end{array}$

\section{Acknowledgements}

The authors acknowledge general support from the School of Chemistry, National University of Ireland (NUI), Galway. This research is funded by Vietnam National Foundation for Science and Technology Development (NAFOSTED) under grant no. 103.03-2018.366.

\section{References}

1 C. C. Benz and C. Yau, Nat. Rev. Cancer, 2008, 8, 875-879.

2 S. Reuter, S. C. Gupta, M. M. Chaturvedi and B. B. Aggarwal, Free Radical Biol. Med., 2010, 49, 1603-1616.

3 E. R. Milaeva, Curr. Top. Med. Chem., 2011, 11, 2703-2713.

4 B. Englinger, C. Pirker, P. Heffeter, A. Terenzi, C. R. Kowol, B. K. Keppler and W. Berger, Chem. Rev., 2019, 119, 15191624.

5 C. G. Hartinger, A. D. Phillips and A. A. Nazarov, Curr. Top. Med. Chem., 2011, 11, 2688-2702.

6 F. Ponte, I. Ritacco, G. Mazzone, N. Russo and E. Sicilia, Inorg. Chim. Acta, 2018, 470, 325-330.

7 Z. Liu, I. Romero-Canelón, B. Qamar, J. M. Hearn, A. Habtemariam, N. P. E. Barry, A. M. G. Pizarro, J. Clarkson and P. J. Sadler, Angew. Chem., Int. Ed., 2014, 53, 3941-3946.

8 G. S. Yellol, A. J. Donaire, G. Yellol, V. Vasylyeva, C. Janiak and J. Ruiz, Chem. Commun., 2013, 49, 11533-11535.

9 L. Flamigni, A. Barbieri, C. Sabatini, B. Ventura and F. Barigelletti, Top. Curr. Chem., 2007, 281, 143-203.

10 S. Ladouceur, K. N. Swanick, S. Gallagher-Duval, Z. Ding and E. Zysman-Colman, Eur. J. Inorg. Chem., 2013, 30, 5329-5343.

11 Y. You and S. Y. Park, J. Am. Chem. Soc., 2005, 127, 1243812439.

12 E. Orselli, R. Q. Albuquerque, P. M. Fransen, R. Fröhlich, H. M. Janssen and L. D. Cola, J. Mater. Chem., 2008, 18, 4579-4590.

13 X.-N. Li, Z.-J. Wu, Z.-J. Si, H.-J. Zhang, L. Zhou and X.-J. Liu, Inorg. Chem., 2009, 48, 7740-7749.

14 P. Brulatti, R. J. Gildea, J. A. K. Howard, V. Fattori, M. Cocchi and J. A. G. Williams, Inorg. Chem., 2012, 51, 3813-3826.

15 Y. Yang, L. Guo, Z. Tian, Y. Gong, H. Zheng, S. Zhang, Z. Xu, X. Ge and Z. Liu, Inorg. Chem., 2018, 57, 11087-11098.

16 A. Petrini, R. Pettinari, F. Marchetti, C. Pettinari, B. Therrien, A. Galindo, R. Scopelliti, T. Riedel and P. J. Dyson, Inorg. Chem., 2017, 56, 13600-13612.

17 V. Novohradsky, Z. Liu, M. Vojtiskova, P. J. Sadler, V. Brabec and J. Kasparkova, Metallomics, 2014, 6, 682-690.

18 C. Wang, J. Liu, Z. Tian, M. Tian, L. Tian, W. Zhao and Z. Liu, Dalton Trans., 2017, 46, 6870-6883.

19 J. P. Cerón-Carrasco, J. Ruiz, C. Vicente, C. de Haro, D. Bautista, J. Zuniga and A. Requena, J. Chem. Theory Comput., 2017, 13, 3898-3910.

20 J. Li, L. Guo, Z. Tian, M. Tian, S. Zhang, K. Xu, Y. Qian and Z. Liu, Dalton Trans., 2017, 46, 15520-15534.

21 D. Malešev and V. Kuntić, J. Serb. Chem. Soc., 2007, 72, 921939.

22 M. M. Kasprzak, A. Erxleben and J. Ochocki, RSC Adv., 2015, 5, 45853-45877.

23 S. I. Pillai, S. P. Subramanian and M. Kandaswamy, Eur. J. Med. Chem., 2013, 63, 109-117. 
24 M. D. Engelmann, R. Hutcheson and F. Cheng, J. Agric. Food Chem., 2005, 53, 2953-2960.

25 L. Dangleterre and J.-P. Cornard, Polyhedron, 2005, 24, 15931598.

26 Y. A. Davila, M. I. Sancho, M. C. Almandoz and S. E. Blanco, Spectrochim. Acta, Part A, 2012, 95, 1-7.

27 K. Vijayaraghavan, S. I. Pillai and S. P. Subramanian, Eur. J. Pharmacol., 2012, 680, 122-129.

28 N. A. E. Ragehy, M. Abdelkawy and A. E. Bayoumy, Anal. Lett., 1994, 27, 2127-2139.

29 A. Andrade, S. F. Namora, R. G. Woisky, G. Wiezel, R. Najjar, J. A. A. Sertié and D. de O. Silva, J. Inorg. Biochem., 2000, 81, 23-27.

30 A. T. M. Fiori, W. R. Lustri, A. Magalhães and P. P. Corbi, Inorg. Chem. Commun., 2011, 14, 738-740.

31 C.-H. Leung, H.-J. Zhong, H. Yang, Z. Cheng, D. S.-H. Chan, V. P.-Y. Ma, R. Abagyan, C.-Y. Wong and D.-L. Ma, Angew. Chem., Int. Ed., 2012, 51, 9010-9014.

32 K. K.-W. Lo and K. Y. Zhang, RSC Adv., 2012, 2, 12069-12083. 33 M. J. Frisch, G. W. Trucks, H. B. Schlegel, G. E. Scuseria, M. A. Robb, J. R. Cheeseman, G. Scalmani, V. Barone, B. Mennucci, G. A. Petersson, H. Nakatsuji, M. Caricato, X. Li, H. P. Hratchian, A. F. Izmaylov, J. Bloino, G. Zheng, J. L. Sonnenberg, M. Hada, M. Ehara, K. Toyota, R. Fukuda, J. Hasegawa, M. Ishida, T. Nakajima, Y. Honda, O. Kitao, H. Nakai, T. Vreven, J. A. Montgomery Jr, J. E. Peralta, F. Ogliaro, M. Bearpark, J. J. Heyd, E. Brothers, K. N. Kudin, V. N. Staroverov, T. Keith, R. Kobayashi, J. Normand, K. Raghavachari, A. Rendell, J. C. Burant, S. S. Iyengar, J. Tomasi, M. Cossi, N. Rega, J. M. Millam, M. Klene, J. E. Knox, J. B. Cross, V. Bakken, C. Adamo, J. Jaramillo, R. Gomperts, R. E. Stratmann, O. Yazyev, A. J. Austin, R. Cammi, C. Pomelli, J. W. Ochterski, R. L. Martin, K. Morokuma, V. G. Zakrzewski, G. A. Voth, P. Salvador, J. J. Dannenberg, S. Dapprich, A. D. Daniels, O. Farkas, J. B. Foresman, J. V. Ortiz, J. Cioslowski, and D. J. Fox, Gaussian 09, Revision E.01Gaussian, Inc., Wallingford CT, 2013.

34 P. J. Hay and W. R. Wadt, J. Chem. Phys., 1985, 82, 299-310. 35 I. Avilov, P. Minoofar, J. Cornil and L. D. Cola, J. Am. Chem. Soc., 2007, 129, 8247-8258.

36 J. Tomasi, B. Mennucci and R. Cammi, Chem. Rev., 2005, 105, 2999-3093.

37 A. Galano, G. Mazzone, R. Alvarez-Diduk, T. Marino, J. R. Alvarez-Idaboy and N. Russo, Annu. Rev. Food Sci. Technol., 2016, 7, 335-352.
38 B. Orwat, E. Witkowska, I. Kownacki, M.-J. Oh, M. Hoffmann, M. Kubicki, I. Grzelak, B. Marciniec, I. Glowacki, B. Luszczynska, G. Wiosna-Salyga, J. Ulanski, P. Ledwon and M. Lapkowski, Dalton Trans., 2017, 46, 9210-9226.

39 A. Kurzwernhart, W. Kandioller, C. Bartel, S. Bachler, R. Trondl, G. Muhlgassner, M. A. Jakupec, V. B. Arion, D. Marko, B. K. Kepplerab and C. G. Hartinger, Chem. Commun., 2012, 48, 4839-4841.

40 H. Chiniforoshan, L. Tabrizi, M. Hadizade, M. R. Sabzalian, A. N. Chermahini and M. Rezapour, Spectrochim. Acta, Part A, 2014, 128, 183-190.

41 M. Y. Wong, G. Xie, C. Tourbillon, M. Sandroni, D. B. Cordes, A. M. Z. Slawin, I. D. W. Samuel and E. Zysman-Colman, Dalton Trans., 2015, 44, 8419-8432.

42 Y. Zhong and F. Shahidi, Woodhead Publ. Ser. Food Sci., Technol. Nutr., 2015, 287-333.

43 S. Sampath, B. Kalimuthu, V. Veeramani, S. Janardhanam, M. A. Baran and R. Chellan, RSC Adv., 2016, 6, 12382-12390. 44 N. Söylemez, E. Yabas, S. Sahin-Bolukbasi and M. Sülü, J. Porphyrins Phthalocyanines, 2018, 22, 233-242.

45 S. Gligorovski, R. Strekowski, S. Barbati and D. Vione, Chem. Rev., 2015, 115, 13051-13092.

46 N. Sreejayan and M. N. A. Rao,J. Pharm. Pharmacol., 1997, 49, 105-107.

47 I. Ejidike and P. Ajibade, Molecules, 2015, 20, 9788-9802.

48 O. Friaa and D. Brault, Org. Biomol. Chem., 2006, 4, 24172423.

49 Q. U. Ain, U. Ashiq, R. A. Jamal and M. Mahrooof-Tahir, Spectrochim. Acta, Part A, 2013, 115, 683-689.

50 I. Nakanishi, T. Kawashima, K. Ohkubo, H. Kanazawa, K. Inami, M. Mochizuki, K. Fukuhara, H. Okuda, T. Ozawa, S. Itoh, S. Fukuzumi and N. Ikota, Org. Biomol. Chem., 2005, 3, 626-629.

51 L. Tabrizi, D. Q. Dao and T. A. Vu, $R S C A d v .$, 2019, 9, 33203335.

52 J. S. Wright, E. R. Johnson and G. A. DiLabio, J. Am. Chem. Soc., 2001, 123, 1173-1183.

53 IP value phenol calculated at the same B3LYP/6-31G(d) level of theory is $185.56 \mathrm{kcal} / \mathrm{mol}$ in the gas phase.

54 A. Galano and A. Martínez, J. Phys. Chem. B, 2012, 116, 12001208.

55 J. R. Leon-Carmona and A. Galano, J. Phys. Chem. B, 2011, 115, 4538-4546.

56 A. Galano, Phys. Chem. Chem. Phys., 2011, 13, 7178-7188.

57 A. Galano, J. Mex. Chem. Soc., 2015, 59, 231-262. 